NBER WORKING PAPER SERIES

\title{
WINNERS AND LOSERS IN INTERNATIONAL TRADE: THE EFFECTS ON U.S. PRESIDENTIAL VOTING
}

\author{
J. Bradford Jensen \\ Dennis P. Quinn \\ Stephen Weymouth \\ Working Paper 21899 \\ http://www.nber.org/papers/w21899 \\ NATIONAL BUREAU OF ECONOMIC RESEARCH \\ 1050 Massachusetts Avenue \\ Cambridge, MA 02138 \\ January 2016
}

Some of the analysis in the paper was conducted at the Center for Economic Studies at the U.S. Census Bureau. Any opinions and conclusions expressed herein are those of the authors, and do not necessarily represent the views of the U.S. Census Bureau. All results have been reviewed to ensure that no confidential information is disclosed. We thank James Vandeventer for excellent research assistance and Annalisa Quinn for editorial assistance. Kent Carlson, Brian Saba, and Jennifer Yan participated in a student working group on economic voting in spring 2012, and we thank them as well. Alexis Antoniades, Quynh Nguyen, and Pietra Rivoli offered helpful comments on drafts. We thank participants at the Mortara Georgetown Political Economy series, the University of Rochester, an American Political Science Association 2015 panel, the Center for International Studies seminar at ETH/University of Zurich, an International Political Economy Society 2015 panel, New York University-Abu Dhabi, Georgetown-Qatar, and a World Trade Institute (Bern) seminar for helpful comments on earlier drafts. All remaining errors of fact and analysis are our own. The views expressed herein are those of the authors and do not necessarily reflect the views of the National Bureau of Economic Research.

NBER working papers are circulated for discussion and comment purposes. They have not been peerreviewed or been subject to the review by the NBER Board of Directors that accompanies official NBER publications.

(C) 2016 by J. Bradford Jensen, Dennis P. Quinn, and Stephen Weymouth. All rights reserved. Short sections of text, not to exceed two paragraphs, may be quoted without explicit permission provided that full credit, including $(\mathcal{C}$ notice, is given to the source. 
Winners and Losers in International Trade: The Effects on U.S. Presidential Voting

J. Bradford Jensen, Dennis P. Quinn, and Stephen Weymouth

NBER Working Paper No. 21899

January 2016

JEL No. F0,F5

\begin{abstract}
This paper studies how international trade influences U.S. presidential elections. We expect the positive employment effects of expanding exports to increase support for the incumbent's party, and job insecurity from import competition to diminish such support. Our national-level models show for the first time that increasing imports are associated with decreasing incumbent vote shares, and increasing exports correlate with increasing vote shares for incumbents. These effects are large and politically consequential. We also construct U.S. county-level measures of employment in high- and low-skill tradable activities. We find increases in incumbent vote shares in counties with concentrations of employment in high-skilled tradable goods and services, and decreases in counties with concentrations of employment in low-skilled manufactured goods. Incumbent parties are particularly vulnerable to losing votes in swing states with high concentrations of low-skilled manufacturing workers with increasing trade exposure. Thus there is an Electoral College incentive to protect this sector.
\end{abstract}

\author{
J. Bradford Jensen \\ McDonough School of Business \\ Georgetown University \\ Washington, DC 20057 \\ and Peterson Institute for \\ Unternational Economics \\ and also NBER \\ jbj24@georgetown.edu \\ Dennis P. Quinn \\ McDonough School of Business \\ Georgetown University \\ Washington, DC 20057 \\ quinnd@georgetown.edu
}

\author{
Stephen Weymouth \\ McDonough School of Business \\ Georgetown University \\ Washington, DC 20057 \\ sw439@georgetown.edu
}


Do the economic effects of international trade influence who wins the U.S. presidency? National-level ("macro") studies show that voters are more likely to reward incumbent presidents and their parties during good economic times, and to reward the opposition when economic conditions deteriorate. ${ }^{2}$ We propose that exposure to global economic integration has an independent effect—separate from trade's effects on economic performance per se —on voting in U.S. presidential elections. Of particular interest is the U.S. economy's growing integration into the world economy, with the resulting direct and indirect effects on growth, employment, wages, and job security. In the only study on the direct effect of economic integration on U.S. presidential voting, Margalit (2011) uses county-level analyses to demonstrate that job loss from import competition—measured as applications for Trade Adjustment Assistance (TAA)—has a negative aggregate effect on incumbent vote share. ${ }^{3}$ In this paper, we develop comprehensive measures of trade exposure using Census data covering nearly all economic activity in the United States. In national- and county-level analyses, we find systematic evidence that U.S. presidential voting reflects winners and losers in international trade: rising exports and vulnerability of employment to import competition help determine U.S. presidential elections.

${ }^{2}$ Initial works in the area include Fair (1978) and Tufte (1978). Other contributions include the papers in a 2008 special issue of the Journal of International Forecasting (Campbell and LewisBeck 2008). See also Fair 2009, Erikson 2009a, Lewis-Beck and Stegmaier 2000, and LewisBeck and Nadeu 2011. Lewis-Beck and Tien (2008) provide a comprehensive review of the literature. See also the April 2014 special issue of PS, "US Presidential Election Forecasting." ${ }^{3}$ Antoniades and Calomiris (2014) study county-level presidential voting and find that constrained credit conditions hurt incumbent vote shares. 
Along with trade's direct effects on employment and wages, we expect worker (voters) to respond to the increased uncertainty that they feel from the threat that trade competition will alter the terms of their employment and wages (or lead to job losses altogether). ${ }^{4}$ Voters employed in industries that face import competition or the prospect that their U.S. employers will relocate to another country (i.e., those employed in low-skill, comparative disadvantage industries) are likely to experience greater uncertainty and to respond by voting against incumbents and incumbent parties. Conversely, employees of firms in industries that are likely to enjoy greater opportunities from globalization (i.e., high-skill industries in which the United States has a comparative advantage) are more likely to demonstrate their satisfaction with their economic position by voting for incumbents.

Since some of the uncertainty workers feel is associated with the threat that their jobs will be lost due to international trade, measures of unemployment and economic growth alone are unlikely to capture the full effect of trade on workers' voting behavior. Levels of employment, the quality and composition of employment, and wage levels will be affected in different ways by exports and imports, and by firms' competitive positions in the global economy. Workers will experience their exposure to changes in import competition or export successes (i.e., the international 'contestability' of their job) before these trade activities affect growth or disposable income.

\footnotetext{
${ }^{4}$ Scheve and Slaughter (2004) demonstrate that wage and employment volatility from international economic integration in the form of foreign direct investment increases workers' economic insecurity.
} 
We expect, therefore, voting in presidential elections to reflect employment levels in winning and losing sectors. Voters employed in firms in comparatively disadvantaged sectors will respond to international competition by voting against incumbents and incumbent parties. Conversely, employees in 'winning' (i.e., tradable, high-skill) sectors are more likely to demonstrate their satisfaction with their economic position by voting for incumbents. Because of differences in industry structure — and thus differences in exposure to trade-across the United States, there will be significant variation in voters' experiences with trade. Some will have benefited from trade due to increasing demand, while others will have experienced rising economic and job insecurity due to increasing import market contestability. We expect geographic concentrations of employment in firms in comparatively advantaged (disadvantaged) sectors to be associated with increasing (decreasing) incumbent vote shares.

We first adapt the core models and methods of the economic voting literature to examine these arguments at the macro (national) level. ${ }^{5}$ We add changes in the U.S. trade balance as a variable of interest to national-level voting models. Our analysis indicates that trade contains information that is different from measures of growth and employment.

However, national-level analyses have limited numbers of observations and a high level of aggregation; therefore, they are unable to identify the industrial and geographic distributional consequences of trade. Precisely because trade creates geographically diverse winners and

\footnotetext{
${ }^{5}$ We do not seek to identify a single 'right' model of economic voting. Rather, we assume that each of the main scholarly models of economic voting has merit, but that much can be gained from examining the role of international trade and considering subnational variation in exposure to trade.
} 
losers, the effects of the varied distributional consequences of trade on voting cannot be studied using national-level vote data.

We therefore also examine our argument at the county level using U.S. census data to measure employment in firms that stand to gain and lose from trade liberalization. ${ }^{6}$ To capture county-level variation in trade exposure within sectors, we rely on confidential, establishmentlevel data from the Census Bureau's Longitudinal Business Database (LBD), which contains information on plants and other establishments in the Census Bureau's County Business Patterns (CBP) program. ${ }^{7}$ The CBP program covers most of the country's private sector economic activity. ${ }^{8}$ The data allow us to measure the number of employees (1) engaged in tradable activities and producing goods and services for which the United States has a comparative advantage (e.g., high skilled, capital intensive) and (2) in positions vulnerable to import competition, such as low-skilled manufacturing. ${ }^{9}$ We estimate how county-level variation in employment in firms in comparatively advantaged and disadvantaged sectors affects voting in U.S. presidential elections.

${ }^{6}$ Jensen (2013) is the first study in political science to examine firm-level confidential microdata collected by the U.S. government.

${ }^{7}$ See Jarmin and Miranda (2002).

${ }^{8}$ The major exclusions are self-employed individuals, employees of private households, railroad employees, agricultural production employees, and most government employees.

${ }^{9}$ We use "tradability" as defined in Jensen and Kletzer (2006) and conceptualize tradable activities as those that are internationally "contestable" as described in Leamer (2007). See below for a more detailed discussion. 
Another important virtue of the county-level data is that it allows us to disaggregate results by state groupings. ${ }^{10}$ We compare the estimated results in swing states (in which the outcomes of U.S. presidential elections are generally determined) to those of non-swing states using several categorizations of swing states.

The core findings of the paper are as follows. At the national level, rising imports and declining trade balances (rising exports) as a percentage of GDP are associated with lower (higher) incumbent vote shares. At the county level, a high concentration of economic activity in comparatively disadvantaged sectors (low-skilled manufacturing) decrease incumbent vote shares, while a high concentration of economic activity in comparatively advantaged sectors (high-wage, tradable services) increase incumbent vote shares. Our results indicate that higher volatility in unemployment is strongly negatively associated with incumbent vote shares. To our knowledge, we are the first to demonstrate that increasing employment in high-skilled tradable services affects voting and that increasing exports (imports) are associated with increases (decreases) in the incumbent party's presidential vote share at the national level. In another innovation, we find that the electoral effects of low-skill manufacturing are concentrated in the swing states, giving rise to an Electoral College incentive toward protecting low-skilled manufacturing.

\footnotetext{
${ }^{10}$ An alternative to counties are commuting zone (CZ) or labor market (LM) data from either the Department of Agriculture or the Census Bureau, respectively. We rely on county level analysis because voting data per se are not collected for either CZs or LMs.
} 


\section{Presidential Voting and U.S. Trade Integration}

\section{Prior Studies}

Prior studies provide overwhelming evidence that economic outcomes affect presidential voting. Starting with the Fair (1978) and Tufte (1978) models, scholars have empirically demonstrated that positive economic performance strongly improves either incumbent or incumbent party reelection prospects. ${ }^{11}$ Research has focused primarily on which factors explain changes in incumbent party vote share.

The macro voting models used in these studies are necessarily parsimonious because of the few degrees of freedom involved in the data. ${ }^{12}$ Invariably, macro models see certain aspects of economic performance as the key determinants of incumbent vote shares: economic growth (Fair 2009), disposable income, employment, job growth (Lewis-Beck and Tien 2008), and business sentiment (Erikson 2009) are contending variables. Quinn and Woolley (2001) show that economic volatility drives down vote shares for incumbent candidates and parties in a comparative, cross-national setting. ${ }^{13}$ Despite the growing prominence of trade issues in political discourse, we know relatively little about how trade affects U.S. presidential voting.

${ }^{11}$ See the reviews in Campbell 2008, Kayser and Leininger 2015, and Lewis-Beck and Tien 2008.

${ }^{12}$ Most studies date from either 1948 or 1952, owing to changes in the U.S. economy after the Second World War. Fair (2009), discussed below, is an exception.

${ }^{13}$ For a contending view on the effects of economic volatility, see Hibbs (2000), who suggests that volatility is not relevant in the U.S. setting at the macro level. 
We do know that globalization has had strong political effects in various other settings. Milner (1988) and Jensen, Quinn, and Weymouth (2015) demonstrate that whether (and how) firms are internationally engaged economically through their global supply chains and trade patterns explains their political engagement on trade issues. Examining survey data, Scheve and Slaughter (2004) find that inward foreign direct investment—and globalization more generally— increases wage and employment volatility, leading workers to feel economically insecure. Similarly, Walter (2010) finds in a study of Swiss respondents that individuals hurt by trade are more likely to report economic insecurity. Mansfield and Mutz (2013) examine survey data to explain the political contentiousness of offshoring. Kayser and Peress (2012) decompose economic growth into domestic and exogenous (international shock) components, and find the voters punish incumbents for national performance that lags international performance. ${ }^{14}$ Despite these advances, this literature has yet to examine how exposure to trade affects citizen voting choices.

Following Rogowski $(1987,1990)$, who argues that political divisions over trade reflect factor-based distributional concerns, a number of studies link the expected winners and losers of global trade and financial flows to U.S. international economic policymaking in Congress. Hiscox (2002) finds that legislator support for trade between 1824 and 1994 reflects the expected gains and losses experienced by class- and industrial-based constituencies. Other studies examine how industry structure at the district level, which proxies for concentrations of voters with

\footnotetext{
${ }^{14}$ They exclude the U.S. from their analytic consideration because their modeling assumption that international economic performance is exogenous to domestic incumbent policy choices is unsound in the U.S. case (2012, 666, fn. 9).
} 
similar economic interests, influences legislator voting on trade and other international economic policymaking issues. ${ }^{15}$ Districts with concentrations of high-skilled voters are associated with greater legislator support for trade (Milner and Tingley 2011), and for outlays in the form of financial rescues (Broz 2005) and funding the International Monetary Fund (Broz and Hawes 2006). Feigenbaum and Hall (2015) study the specific effects of economic shocks from Chinese import competition, and find that legislators from exposed districts vote in a more protectionist manner. Rickard (2015) demonstrates the linkage between export success in a Congressional House member's district and his or her likelihood to support TAA, and Owen (2015) finds that the 'offshorability' of jobs in a Congress member's district decreases the likelihood of voting in favor of a trade agreement. If trade has the distributional consequences implied by these studies and developed in the ensuing section, voters who are harmed by (benefit from) trade will be more likely to shift away from (toward) the incumbent or the incumbent's party.

Our contribution emphasizes the effects of changing exposure to international economic competition on presidential voting. Increased trade, particularly greater exposure to import competition, reflects changes in voter economic experiences that are not immediately captured by changes in growth or personal income. For instance, economic growth effects will likely lag because of government policies that intentionally slow the effects of trade adjustment, and due to slow reactions by import competing firms that shed workers. Furthermore, wages and jobs are sticky due to a number of factors (e.g., unemployment insurance, buyouts, and the lag between import surges and how firms respond), which implies a delay between the immediate effects on

\footnotetext{
${ }^{15}$ An important assumption of this work is that the distributional consequences of policy depend on local-level economic characteristics.
} 
firms and the longer-term effects on growth. We will demonstrate empirically that the effects of trade are not simply subsumed by growth or aggregate unemployment.

In summary, American politics scholars have found that economic factors explain incumbent party presidential vote shares in macro models of voting. Scholars in the international political economy literature have shown that trade flows and employment contestability influence both public opinion and other facets of political behavior. With the exception of Margalit (2011), however, there is little work on the direct effects of trade on U.S. presidential voting. Therefore we examine how trade and trade-contested employment influence voting in the context of extant national and county-level models. We contribute to both literatures by providing an account of how trade exposure across sectors and regions influences presidential voting.

\section{The Possible Effects of Trade Integration on U.S. Presidential Voting}

Because the United States is a relatively high-skill-abundant country, it has a comparative advantage in high-skill activities, and a comparative disadvantage in low-skill activities. Thus, firms in low-skill, labor-intensive tradable goods industries tend to face greater import competition, especially as trade agreements have brought previously trade-isolated countries, especially China, into the global economy. ${ }^{16}$ Low-skilled workers in these U.S. firms are threatened by rising imports from labor abundant countries, which have dramatically expanded

\footnotetext{
${ }^{16}$ Bernard, Jensen, and Schott (2006) document these patterns. One study finds that import competition resulting from China's integration into the world trade system explains a quarter of the decline in U.S. manufacturing employment since 1990 (Autor, Dorn, and Hanson 2013).
} 
exports in labor-intensive industries. U.S. firms in import-competing industries that do not shift production to low-wage countries are likely to fail or to change industries as a result of this competition (Jensen, Quinn, and Weymouth 2015). Plant closures and/or the redeployment of production abroad produce lower employment and slower wage growth in the United States among these less competitive (“comparatively disadvantaged") firms (Bernard, Jensen, and Schott 2006).

While manufacturing employment in the United States has contracted due in part to import competition, previous empirical research suggests that the distributional consequences of trade vary across industries (and across firms within industries) according to comparative advantage. For example, Bernard, Jensen, and Schott (2006) find that manufacturing establishments in industries facing higher import competition from low-wage, labor-abundant countries experience higher exit rates and slower employment growth. In contrast, manufacturing establishments with factor intensities that are consistent with areas of U.S. comparative advantage (high skill- and capital-intensive industries) are less likely to exit. We expect these uneven distributional effects of trade to shape voter attitudes toward trade and their voting in presidential elections.

It is conventional to distinguish between service and manufacturing sectors in terms of employment. Previous empirical literature strongly suggests that workers with similar skills receive higher wages in the manufacturing sector than in the service sector. ${ }^{17}$ Because workers in the manufacturing sector earn higher wages (even after controlling for skill), and that premium is significantly reduced if the worker leaves the manufacturing sector, we expect that these workers

\footnotetext{
${ }^{17}$ See, for example, Krueger and Summers (1988).
} 
will be more threatened by the prospect of being displaced from their job than workers in the service sector.

We expect services trade contestability to also influence presidential elections. While most empirical work in international trade focuses on the manufacturing sector, Jensen and Kletzer (2006) and Jensen (2011) examine the extent to which service activities are tradable and explore the exposure of U.S. service industries to international competition. They find that a large share of service activities (particularly business service activities) is tradable. Jensen (2011) argues that tradable business service activities are consistent with U.S. comparative advantage (the United States runs a persistent and growing trade surplus in services), and that therefore, workers in high-skill tradable services activities will benefit from the increased tradability of services.

We note here that traded services are those as defined by balance of payments accounting conventions and by the World Trade Organization. ${ }^{18}$ Tradability differs conceptually from the notion of 'offshorability'. We conceptualize industries as being tradable based on the geographic concentration of production in the United States. ${ }^{19}$ Offshorability, on the other hand, relates to

\footnotetext{
18 The modes of service trade are described by the World Trade Organization (WTO) as being cross-border exports ("Mode 1"); services consumption abroad ("Mode 2"); a commercial presence abroad ("Mode 3); and foreign services contractors abroad ("Mode 4"). See https://www.wto.org/english/tratop_e/serv_e/cbt_course_e/c1s3p1_e.htm\#boxa.

${ }^{19}$ Geographically concentrated industries, such as apparel production or financial services, are deemed to be tradable. Industries like concrete production and grocery stores, which exhibit
} 
the ability to perform work from abroad (Blinder and Krueger 2013). While offshorability implies that the activity is tradable, not all tradable services are offshorable. ${ }^{20}$ For instance, tradable service industries include U.S. based tourism-related industries.

Thus, we distinguish between and among: goods and services that are tradable vs. nontradable (i.e., internationally contestable or not), high- vs. low-skill work (consist with U.S. comparative advantage), and manufacturing vs. services industries (owing to inter-industry wage differentials). Given these distinctions, we propose that:

- Low-skill tradable manufacturing workers will experience deep exposure and vulnerability to international trade competition because their products are tradable and use intensively factors in which the U.S. lacks comparative advantage. Moreover, low-skill manufacturing workers receive a relatively large inter-industry wage differential compared to peers in service sector work.

- High-skill tradable service workers are likely to gain from increased globalization because of the U.S. comparative advantage in high-skilled activities consistent with U.S. factor abundance in educational attainment.

geographically dispersed production, are classified as non-tradable. See the empirical section for further details.

${ }^{20}$ An important limitation of the classification scheme of offshorability for this study is that most manufacturing production jobs require the worker to be physically present to complete a task. Thus, manufacturing industries often end up being classified as 'non-tradable' because of nonoffshorability, against all reasonable evidence. Most manufacturing is clearly contestable by imports. See Jensen and Kletzer (2006, 2010) for discussions. 
- We have ambiguous expectations regarding the benefits of trade to high-skilled workers in tradable manufacturing. High-skilled workers have a wage premium (owing to inter-industry wage differentials) that contributes to the import vulnerability of the sector (i.e., wages are higher than skills would require). However, the United States has factor abundance in skilled workers, which some U.S. manufacturing firms use intensively.

- We also have ambiguous expectations regarding the benefits and costs to workers in lowskill tradable services. It is not clear that these workers recognize the international exposure of their industry. Moreover, the risks that these workers will be displaced are lower because their alternative employers pay similarly (that is, services have lower inter-industry wage differentials).

Our theoretical framework emphasizes a spatial distribution of winners and losers from trade reflective of the industrial composition. Because trade changes the composition of firms in the economy, it is not just the quantity of work in the import-competing sectors that declines, but also its quality and composition in terms of wages, benefits, and job security. Workers in comparatively disadvantaged tradable sectors recognize that their jobs are contestable and are thus vulnerable to increased trade competition. Trade is likely to affect workers before the effects of either imports or exports are reflected in the unemployment rate. Even before importcompeting firms cut jobs, workers can anticipate the effects of reduced production orders (e.g., shorter hours, reduced wages, and eventual lay-offs). Employees of firms in the importcompeting sector might retain their jobs or find new ones, but the terms of employment are likely to worsen in quality. Employees of firms trading in industries in which the United States has a comparative advantage are more likely to be satisfied with U.S. integration. These heterogeneous 
distributional consequences imply that subnational voting for incumbent parties will reflect concentrations of employment activity in winning and losing firms.

In summary, we expect that the varied consequences of globalization across firms will affect voting, with the principal beneficiaries of globalization (those employed in exporting firms, most often in sectors of U.S. comparative advantage) more likely to vote for the incumbent. In contrast, we expect lower-skilled employees of firms conducting low-skill activities in tradable sectors to be more likely to express their dissatisfaction by voting against the incumbent.

\section{Implications}

We examine the empirical implications of our argument at the country and county levels.

At the national level, we expect:

- Imports (exports) will be associated with decreased (increased) support for the incumbent. The effects will be especially concentrated in the manufacturing sector.

At the county level, we expect:

- The concentration of employment in comparatively advantaged firms (high skill/ tradable) will be associated with increasing support for the incumbent.

- The concentration of employment in comparatively disadvantaged firms (low-skill/ tradable) will be associated with decreasing support for the incumbent. 


\section{Empirical Analysis}

\section{Analytic Considerations}

The standard approach in the national-level economic voting literature has been to estimate ordinary least squares (OLS) time-series models of incumbent party presidential vote shares with a necessarily parsimonious set of explanatory variables. While investigators differ in specifications, the most commonly used approach contains measure(s) of economic performance, voter sentiment, and prior incumbency, or vote share. We adopt that approach here, adding trade variables to the models.

Because the list of plausible measures of the explanatory variables of Incumbent Vote Share $e_{t}$ exceeds the plausible degrees of freedom given at most 20 observations, the issue of omitted variable bias in the estimations arises. As noted above, prior incumbent vote share (IncVoteShare t-1) is a plausible correlate of current vote share, and is entered to attenuate this possible bias. ${ }^{21}$ The timing of the variables is such that monthly data (when available) after the presidential elections in November are excluded. In most of our models, the investigation starts with the 1952 data. The variables, yearly coverage, and their sources are described in online Appendix D.

Additional independent variables used in prior studies include retrospective indicators of economic performance: per capita real economic growth, changes in personal disposable income, job growth during a presidential term (Lewis-Beck and Tien 2004), inflation during the 12 months prior to the election, and changes in unemployment. Common variables for representing voter sentiment are perceived business confidence in quarter 15 (Erikson 2009), net candidate

\footnotetext{
${ }^{21}$ The absence of a cross-sectional dimension to the data precludes the use of unit fixed effects.
} 
advantage (Erikson 1989), and presidential approval in the election year July Gallup poll (Abramowitz 2008; Lewis-Beck and Tien 2004). We also examine the valence vs. partisan effects of economic conditions, as suggested by Wright $(2012)$. Abramowitz $(1988,2008)$ also incorporates how long a party has governed in terms of the "costs of governing." As we do not take a stand on the 'right' macro model, we present many variants of the models with these regressors.

The variables are likely to contain overlapping information, and cannot all be entered in any event owing to limited degrees of freedom. To explore both the identifying and commonpool variances contained in the explanatory variables, we undertake factor analysis. Given the need to avoid omitted variable bias while maintaining a parsimonious model, factor analysis can help determine which measures of the baseline model provide unique identifying variances.

The details of the factor analysis appear in Appendix A. Here we discuss the implications of the estimates. First, it is likely that whichever of the various economic growth indicators are used, substantively similar results will be obtained. This is likely true for the sentiment/approval indicators as well, a supposition that is explored below.

In contrast, the evidence suggests that $\triangle$ Imports/GDP is not subsumed in the other factors, and, as indicated by its 'uniqueness score,' contains useful identifying variance. The $\triangle$ Exports/GDP indicator, in contrast, is likely to overlap in information with the economic performance and voter sentiment variables. (The $\triangle$ Trade Balance/GDP does not load on any factor.) Hence, the trade variables partly contain independent information. 
The county-level factor analysis shows far less information overlap. ${ }^{22}$ The county-level measures, however, do not include some important variables of interest, including county-level trade balance and public opinion. We therefore propose that a joint consideration of the nationaland macro-level results is best suited for this investigation. We begin with the national-level analysis in the next section.

\section{National Voting}

Macro Data and Models. The dependent variable is the post-war incumbent party's share of the two main party presidential votes (Incumbent 2-Party Vote Share ${ }_{t}$ ) from 1952 to 2012. The sample is determined by the availability of quarterly data on economic growth. ${ }^{23}$ We also estimate a model, 1936-2012, using data from Fair (2009). The passage of the Reciprocal Trade Agreements Act (RTAA) of 1934 repealed the Smoot-Hawley Tariff, and is widely seen as marking the modern era of U.S. trade integration. ${ }^{24}$ In light of prior theory and statistical testing, the base time-series macro model to be estimated is:

\footnotetext{
${ }^{22}$ Details available upon request.

${ }^{23}$ Quarterly data for the four quarters prior to the election (Q12 through Q15) are used rather than annual growth data (Q13 through Q16). The latter indicator includes information for the 53 to 59 days of economic activity after the election (depending on the date of the election in a particular year).

${ }^{24}$ See Bailey, Goldstein, and Weingast (1997) and Hiscox (1999) for discussions of the RTAA. As Goldstein (1994) notes, U.S. trade policy post-RTAA contained important legacies of prior
} 
Incumbent 2-Party Vote Share $_{t}=\beta_{0}+\beta_{1}\left(\right.$ Incumbent Vote Share $\left._{t-1}\right)+\beta_{2}\left(\right.$ Economic Growth $\left._{t-1}\right)$

$$
+\varepsilon_{t} t=1952-2012(\mathbf{1})
$$

To this model will be added change in the trade indicators:

either $\beta_{3}\left(\Delta \operatorname{TradeBal} / G D P_{t-1}\right)$ or $\beta_{3^{\prime}}\left(\Delta \operatorname{Import} / G D P_{t-1}\right)$ and $\beta_{4^{\prime}}\left(\Delta \operatorname{Exports} / G D P_{t-1}\right)$, plus an indicator of either Business Sentiment or July Approval: $\beta 5$ (Sentiment/Approval $t-1$ ).

As an initial indicator of economic performance, we use real per capita GDP from Q12Q15. (The choice of the economic growth variable is not influential in the results.) To represent voter sentiment and prospective economic activity, we alternate Business Conditions Q15 (Erikson (2009) the July Gallup (Q15) presidential approval ratings (Abramowitz 2008; LewisBeck and Tien 2008). The trade variables also use data from Q12-Q15. Models with $\Delta$ Imports $/ G D P_{t-1}$ and $\Delta J o b s_{t-1}$ jointly and separately entered are reported. ${ }^{25}$

To assess the statistical adequacy of the models, a number of diagnostic tests are reported. This is especially important in the context of a small number of observations with potentially correlated errors (see Grant and Lebo forthcoming). ${ }^{26}$

protectionist policies and programs, which attenuated slowly over time. Therefore, we expect (and find) weaker estimated effects in earlier periods. Results are available from the authors. ${ }^{25}$ We also estimate a 'least absolute deviations' (or quartile) regression as a robustness check alternative to the main time-series OLS models. OLS can magnify the influence of outliers, in contrast to quartile regressions.

${ }^{26}$ Because the models include some form of lagged endogenous variable, the classical DurbinWatson statistic is replaced with a Lagrange-multiplier (LM) test for first- and second-order residual autocorrelation - the AR 1-2 test. To account for possible error correlation and 
Macro Results. Table 1 reports the main results. In Model 1.1, prior incumbent vote share and economic growth are entered. The estimation properties of the model are good, and the results are consistent with prior findings. In all models reported, economic growth has an estimated coefficient that is positive, significant, and substantively large. The lagged endogenous variable has a negative and significant coefficient, which is consistent with the theories regarding the 'costs of governing' and the standard findings of a decline in incumbent vote margins in subsequent elections. Taking the mean of two party Incumbent Vote Share $t-1$ (53.7\% for the 1948-2008 elections), multiplying it by the parameter estimate, and adding the estimate of the constant to its product produces an estimate of Incumbent Vote Share ${ }_{t}$ of $46.8 \%$, or a $-6.9 \%$ change from the prior election, assuming a zero increase in economic growth. Multiplying the estimated coefficient of growth by the sample mean (a growth rate of 2.2\%) and adding it to the above calculation produces an estimate of Incumbent Vote Share $_{t}$ of $52 \%$. A growth rate of $1.25 \%$ or lower brings the estimate of Incumbent Vote Share ${ }_{t}$ below $50 \%$. The adjusted Rsquared is 0.61 .

In Models 1.2 and 1.3, the trade indicators are entered. Change in the trade balance (Model 1.2) has a statistically significant positive coefficient that is substantively large and consistent with the theory developed above. A one-unit increase (decrease) in the U.S. trade

heteroskedasticity, which can bias standard errors, Newey-West heteroskedasticity and autocorrelation consistent standard errors are reported. A 'normality test for residuals' based upon Jarque-Bera with the Doornik-Hansen small sample correction is also reported. Finally, an ARCH test for conditional first-order heteroscedasticity is reported. Statistically significant pvalues signify assumption violations. 
balance as a percentage of GDP is associated with a $4 \%$ estimated increase (decrease) in incumbent vote shares. ${ }^{27}$ Change in imports (Model 1.3) has a statistically significant negative coefficient, which is substantively large and also consistent with our theory. A one-unit increase (decrease) in imports as a percentage of GDP is associated with a $4 \%$ decrease (increase) in incumbent vote shares. Change in exports as a percentage of GDP has a positive and statistically significant coefficient that is substantively large; a one-unit increase is associated with a $6 \%$ increase in presidential vote shares. The explanatory power of the models, judged via adjusted Rsquared indicators, rises 19 points with the inclusion of the trade variables. ${ }^{28}$

Models 1.4 and 1.5 add the indicators of Business Sentiment Q15 and July Gallup (respectively) to the model with $\triangle T r a d e B a l / G D P_{t-1}$. Both indicators have positive, statistically significant, and substantively large estimated coefficients that are consistent with prior theory and findings. ${ }^{29}$ The inclusion of the Business Sentiment Q15 and July Gallup variables leads to a

${ }^{27}$ Using a quantile estimator for Model 1.2 produces identical signs on the coefficient estimates and similar levels of statistical significance. The coefficient estimates are modestly smaller than the estimates using OLS time-series methods.

${ }^{28}$ Change in exports loads on Factor 1 (Table A3.a) along with the growth indicators. The variable therefore contains overlapping information with the indicators of economic growth. ${ }^{29}$ The Business Sentiment Q15 data are available only from 1954 onward, making the 1956 election the first election in the sample. The July Gallup variable is available from the 1940s onward. In order to compare the estimated effects of change in imports across the different specifications, the 1956-2012 sample is used. The results for the models with July Gallup in the 1952-2012 sample are nearly identical to the models reported. 
marked increase in the explanatory power of the models: from 0.8 with neither to 0.99 for Business Sentiment Q15 and 0.9 for July Gallup. The estimated coefficients of $\triangle$ TradeBal/GDP $t-1$ remain positive and highly statistically significant. Its coefficient estimate is larger in the model including Business Sentiment Q15 (1.4) compared to the model with July Gallup (1.5). Model 1.5, however, shows evidence of statistically significant heteroskedasticity in the residuals.

Using data as of November 2015, Model 1.4 suggests that the nominee of the Democratic Party would comfortably win the two-party popular vote totals. The predicted outcome, however, is fragile to relatively modest changes in economic conditions. For example, if the economic conditions of the fall of 2000, another period in which the dollar appreciated, prevailed — growth at $3 \%$ and an import surge of $1 \%$ of GDP linked to a sharp rise in the value of the U.S. dollar the year before - the Democratic Party candidate is forecast to receive slightly less than $50 \%$ of the two-party vote shares. ${ }^{30}$

In Models 1.6 and 1.7, $\triangle T r a d e B a l / G D P_{t-1}$ is replaced by $\triangle \operatorname{Import}_{\text {G }} G D P_{t-1}$ and $\Delta$ Exports $/ G D P_{t-1}$, and Business Sentiment Q15 and July Gallup, respectively, are included. The models have good estimation properties and explanatory power. The estimated coefficient of $\Delta$ Import/GDP $P_{t-l}$ remains negative and highly statistically significant, and the estimated coefficient of $\triangle$ Export/GDP $_{t-1}$ remains positive and statistically significant.

\footnotetext{
${ }^{30}$ Between November 1999 and November 2000, the trade-weighted value of the U.S. dollar increased by 9\%. Between August 2014 and August 2015, it increased by 15.6\%. (Source: U.S. Federal Reserve Bank of St. Louis (FRED), series TWEXB.)
} 
As a further experiment, we extend the sample back to the 1936 election, which is postRTAA, using data and models from Fair (2009). Model 1.8 enters changes in the trade balance, and Model 1.9 enters changes in imports and exports. The coefficient estimates retain similar signs and levels of statistical significance.

Other variables are not the main focus, but the estimated coefficient of economic growth, while always positive and statistically significant beyond the 0.01 confidence level, is diminished in size with the inclusion of either Business Sentiment Q15 or July Gallup. The coefficient estimates of Business Sentiment Q15 and July Gallup are always positive, statistically significant, and substantively important. ${ }^{31}$

In Appendix Table A4, we use Model 1.3 as the base model and add additional indicators proposed by other investigators. The trade results are strongly robust to including the other regressors. In all cases, the export and import coefficient estimates retain the expected sign, and the estimated coefficients are statistically significant at the 0.1 level or better.

We note here several significant results from the robustness checks. First, the change in manufacturing jobs has a highly statistically significant estimated coefficient, consistent with Lewis-Beck and Tien (2004). Second, when we distinguish between trade in goods and trade in services, the estimated coefficients for trade in goods are highly statistically significant and in the expected direction. The evidence is that trade in goods is largely responsible for the national results found here.

\footnotetext{
${ }^{31}$ Models that include both Business Sentiment Q15 and July Gallup leave neither with statistically significant estimated coefficients, though the trade variable estimates are substantively similar. Details are available upon request.
} 
Finally, in unreported models, we serially interact the independent regressors from the main table and the Appendix table with a Democratic Party incumbent dummy variable to explore possible partisanship effects, but find no interaction effects remotely close to statistical significance. $^{32}$

\section{County-level Voting}

County-level Data and Models. We next examine the determinants of incumbent party vote share at the county level. The baseline OLS, year- and county-fixed effects model is:

$\Delta$ Incumbent 2-Party Vote Share ${ }_{i, t}=\beta_{0}+\beta_{1}\left(\right.$ Unemployment Rate $\left._{i, t}\right)+\beta_{2}\left(\Delta\right.$ Unemployment $_{(1-}$

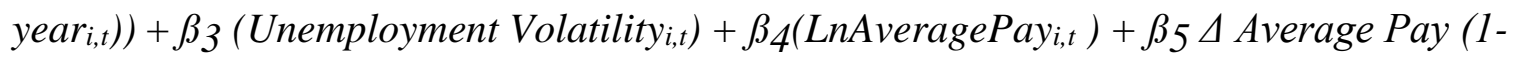
year $_{i, t}+\beta_{6}\left(\right.$ High-Wage Tradable Manufacturing Employment $\left._{i, t}\right)+\beta_{7}($ Low-Wage Tradable Manufacturing Employment $\left.{ }_{i, t}\right)+\beta 8($ High-Wage Tradable Services Employment $\left._{i, t}\right)+\beta 9\left(\right.$ Low $\left._{\text {-Wage Tradable Services Employment }}, t\right)+\varphi_{i}+\tau_{t}+\varepsilon_{i, t} \quad t=1992$, 1996, 2000, 2004, 2008, 2012

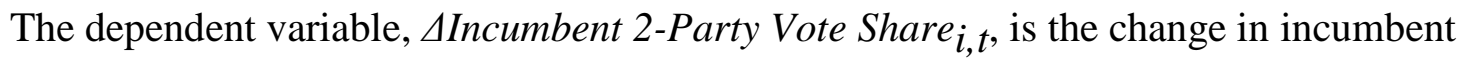
party vote as a share of the total Democratic and Republican votes in county $i$ in year $t$. The models begin in 1992 because the Census LBD coverage of all services industries begins in that

${ }^{32}$ Details available from the authors. One possibility is that the Democratic Party has only recently emerged as the less 'liberalizing' party, and we therefore experiment with a Democratic Party incumbency dummy variable from 1992 onward, but find no statistically significant effects. We thank Larry Rothenberg for the suggestion. 
year. We include county $\varphi_{i}$ and election year $\tau_{t}$ dummies. ${ }^{33}$ Following Margalit (2011), some of our models control for aggregate job losses due to globalization - the lagged sum of the estimated number of workers filing for TAA as a share of the labor force. ${ }^{34}$ Following Wright (2012), some of our models include a Democratic incumbent interaction with either unemployment levels or changes in unemployment (e.g., Democratic Incumbent $x$ AUnemployment $\left.(1-\text { year })_{i, t}\right)$.

We examine the effects of economic instability on voting using county-level data on unemployment and wages. The variable Unemployment Volatility is the standard deviation of the unemployment rate in county $i$ over the 3 years prior to the election year and the election year. ${ }^{35}$ The income data are from the Quarterly Census of Employment and Wages, conducted by the

${ }^{33}$ A Hausman test of random vs. fixed effects rejects the random-effects model: an $\chi^{2}$ test produce a typical value of over 500. An alternative to fixed effects is to include prior incumbent vote share as a regressor (Incumbent 2-Party Vote Share it-1) $_{\text {) }}$ as in Fair (2009) and Powell and Whitten (1993). Diagnostic statistics for the county-level regressions suggest that the fixedeffects model is preferred. At the macro level the lagged vote share is entered, which improves the diagnostic statistics.

${ }^{34}$ The TAA data come from Public Citizen. http://www.citizen.org/Page.aspx?pid=4536 (accessed March 2, 2015).

${ }^{35}$ For example, in 1996, Employment Volatility is the standard deviation of the unemployment rate in county $i$ for the years 1993,1994,1995, and 1996. The unemployment data are from the BLS. 
Bureau of Labor Statistics (BLS). We also enter change in unemployment from the year prior to the election and change in income.

We incorporate a number of different measures of voters' exposure to trade. Our objective is to investigate whether voting behavior is influenced by the international exposure of local industries. Our goal is to examine the international exposure of the entire local economynot merely to assume, for example, that all manufacturing industries are trade exposed. For this task, we need to classify workers according to their skill and the tradability of the goods or services produced by their employer.

Our measures of economic contestability capture employment in high- and low-wage tradable services and manufacturing. We construct these measures using confidential data on the near-universe of economic activity measured at the individual plant level by the U.S. Census Bureau. ${ }^{36}$ We use trade cost estimates to identify all tradable industries in both manufacturing and services. We develop measures of international exposure using confidential data from the U.S. Census Bureau's LBD. We classify establishments into categories based on the sector and the tradability of the industry to construct measures of the numbers of jobs in a county that is potentially exposed to international trade.

\footnotetext{
${ }^{36}$ In the Appendix, we replicate the analysis using publicly available employment location quotients from the U.S. BLS. These data measure the concentration of employment in manufacturing and services. For services, we are able to distinguish between tradable and nontradable services. Our results are consistent with those discussed in this section. See Appendix C for further details.
} 
We identify variation in the tradability among disaggregated industries within the manufacturing and services sectors by adapting the methodology developed in Jensen and Kletzer (2006). ${ }^{37}$ In particular, we use the Gini coefficient of the geographic concentration of production above what would be predicted by local demand to identify tradable industries. ${ }^{38}$ We use the manufacturing sector, for which we feel we understand the tradability of manufactured goods relatively well, as the basis for setting the cutoff for the geographic concentration Gini that signifies tradability. We chose the Gini coefficient that results in $90 \%$ of manufacturing sector employment being classified as tradable as the tradability cutoff. ${ }^{39}$ We use the same Gini threshold as the cutoff for determining tradability in the service sector. If the Gini coefficient for a service industry is above the threshold Gini coefficient that results in $90 \%$ of manufacturing sector employment being classified as tradable, the service industry is classified as tradable.

${ }^{37}$ We classify tradability at the six-digit NAICS level.

38 The intuition of the methodology is that, where trade costs are high (e.g., for grocery stores and barber shops), production will be distributed with demand; for industries that have significant concentrations of production (e.g., financial services, movie production, software publishing), trade costs are low. We classify the manufacturing and service industries as being tradable according to this definition using data from the Economic Census for 1992. For a more formal development of the intuition, see Gervais and Jensen (2013).

${ }^{39}$ See Jensen (2011) for further discussion of choosing a tradability cutoff. 
We classify employment in establishments as high or low skill using the median national household income in the relevant year as the threshold for 'high wage. ${ }^{40}$ Workers are classified as high wage if the establishment in which they work has average wages above the national median household income. Using these data, we are further able to distinguish between employment in high-wage, highly traded industries and employment in non-traded industries. Illustrative examples of tradable industries (with corresponding six-digit North American Industrial Classification System (NAICS) codes) are listed below. ${ }^{41}$ We sum across establishments to capture the number of workers in each county that are in each of the four quadrants.

\begin{tabular}{|l|l|}
\hline $\begin{array}{l}\text { Tradable High-wage Manufacturing } \\
\text { Automobile Manufacturing (336111) } \\
\text { Breakfast Cereal Manufacturing (311230) } \\
\text { Light Truck Manufacturing (336112) }\end{array}$ & $\begin{array}{l}\text { Tradable High-wage Services } \\
\text { Computer System Design Services (541512) } \\
\text { Investment Banking and Securities Dealing } \\
\text { (523110) } \\
\text { Software Publishing (511210) }\end{array}$ \\
\hline $\begin{array}{l}\text { Tradable Low-wage Manufacturing } \\
\text { Carpet and Rug Mills (314110) } \\
\text { Yarn Spinning Mills (313111) } \\
\text { any industry in 313, 314 and most in 315, 316 }\end{array}$ & $\begin{array}{l}\text { Tradable Low-wage Services } \\
\text { Amusement and Theme Parks (713110) } \\
\text { Credit Card Issuing (522210) } \\
\text { Limousine Services (485320) }\end{array}$ \\
\hline
\end{tabular}

${ }^{40}$ Figure C1 in Appendix C demonstrates the strong correlation between wages and skill (education) in both the manufacturing and services sectors.

${ }^{41}$ Examples of non-tradable manufacturing goods include poured concrete (238110) and corrugated and solid fiber boxes (322211); examples of non-tradable services include dentist offices (621210) and full service restaurants (722110). 
We also construct measures of the number of workers in the manufacturing sector, the number of workers at manufacturing establishments that export (derived from establishmentlevel responses to the Census of Manufacturers question about whether the establishment has direct exports), and the number of workers at establishments that export with high and low wages. We aggregate establishment-level employment for each category to the county level. This analysis appears in Appendix C.

The analysis with census microdata includes 3,105 U.S. counties for which complete economic and voting data are available for our period of study (1992-2012). Consistent with Margalit (2011) and Wright (2012), we exclude Alaska because the voting data are reported in districts that cannot be mapped to specific counties.

County-level Results. The baseline results using the census microdata measures are presented in Table 2. We find that higher: tradable/high-wage manufacturing employment, tradable/high-wage services employment, and tradable/low-wage services employment are associated with higher incumbent vote shares. Higher tradable/low-wage manufacturing employment is associated with lower incumbent vote shares. Substantively, a one-standard deviation increase in high-wage tradable manufacturing is associated with a .5\% increase in incumbent vote share. The estimates indicate substantively larger effects of low-wage manufacturing, where a one-standard deviation change is associated with a decrease of $1.3 \%$. For high-wage and low-wage tradable services, a one standard deviation change increases incumbent vote share by $1.3 \%$ and $1.5 \%$, respectively.

Column 2 reports the regression results without population weights. Compared to the baseline (weighted) results, the unweighted results are qualitatively similar for our main variables of interest, with the exception of tradable/high-wage manufacturing employment, 
which is no longer statistically significant. However, the number of workers in tradable lowwage manufacturing is negatively associated with incumbent vote shares, and the number of workers in tradable services (both high and low wage) is associated with increasing incumbent vote shares.

Column 3 reports the results for swing states. There are a few notable differences between the results for swing states and the baseline results. The coefficient estimate for lowwage tradable manufacturing employment is larger than the baseline (approximately double) and statistically significant. High-wage tradable manufacturing and service employment are not statistically significant in the swing states subsample.

Column 4 reports the results for non-swing states. Comparing swing/non-swing states, the coefficient estimate for tradable, low-wage manufacturing employment is about a third of the size in non-swing states compared to swing states. In addition, the tradable, high-wage manufacturing and service employment measures are positively and statistically significantly associated with incumbent vote share.

Column 5 reports the baseline specification plus county-level demographic controls for the full sample of counties. The baseline coefficient estimates are quantitatively very similar to the baseline estimates.

We provide the results of a number of robustness tests designed to subject our analysis to prior findings. To save space, these model estimates appear in Appendix B. Table B.1 demonstrates that TAA is negatively associated with incumbent votes shares, a result that confirms Margalit's (2011) finding from the 2004 presidential election. Our measures of exposure to trade retain statistical significance to the inclusion of TAA, with the exception of 
low-wage tradable manufacturing. This is not surprising, given that TAA is largely designed to address dislocations in that sector.

To examine partisan effects established in the literature, in Table B.2, following Wright (2012), we account for the established argument that unemployment is a partisan issue by including a Democratic Incumbent indicator variable interacted with unemployment (both in levels and changes). The results strongly support Wright's argument that higher unemployment is associated with increasing vote shares for Democrats. Including this interaction term (and its constitutive terms) does not affect our main results.

Table B.3 uses a different measure of exposure to international trade, replacing the geographic concentration-based measures with levels of employment at manufacturing establishments that export. We find a negative relationship between employment in manufacturing firms that export and incumbent vote shares, which appears to be driven by lowwage employment in exporting firms. This is an area for future research.

Our results from the county-level analysis can be summarized as follows. Employment volatility and unemployment vary substantially across the United States, and we find strong evidence that both outcomes significantly reduce support for the incumbent. Counties with more workers in trade-exposed industries that are inconsistent with U.S. comparative advantage (i.e., tradable low-wage manufacturing) are less likely to vote for the incumbent. Counties with more workers in tradable, high-wage manufacturing and tradable services are more likely to vote for the incumbent. The larger coefficient estimate for tradable, low-wage manufacturing employment and the lack of statistical significance on high-wage manufacturing and high-wage services employment in swing states might explain the persistence of policy attention to the manufacturing sector in spite of its declining share of the labor force. 


\section{Conclusion}

Popular accounts in the press and prior academic research indicate that globalizationcharacterized by increases in financial integration, rising exports and import competition, and the offshoring of production — shapes politics through its effects on employment, wages, and economic insecurity. The effects of globalization on the most fundamental political activity (voting) are not well understood, as most models of economic voting to date have ignored trade. Our paper demonstrates that changes in trade flows and in the concentration of employment in firms in winning and losing industries are unique contributors to explaining presidential voting. The results demonstrate that the relative decline in the U.S. trade position in goods over the past two decades has been harmful to incumbent presidents, and suggests that an array of related macroeconomic conditions - currency valuation, China's accession to the WTO, and the increasing export competitiveness of other emerging markets - are potentially consequential for U.S. presidential elections.

We consider variation in the geographic distribution of industry structure in the United States to better understand how trade affects the vote. Our argument is that increases in trade principally benefit the employees of firms in tradable, comparatively advantaged industries and activities, while employees of firms that compete with imports may be dissatisfied with economic integration that increases competition from abroad. Voting will reflect the contestability of employment produced by increasing exposure to trade.

Unlike much of the IPE existing research, our framework does not posit stark political divisions across factors and sectors of the economy. Instead, we expect winners and losers in international trade to be manifested across firms. The contestability of employment depends on 
trade exposure and the degree to which the firms' activities align with traditional factor-based sources of comparative advantage. Winners in international trade see expanding export opportunities and weaker global competition; losers in international trade are exposed to imports from more competitive global rivals.

We examine our argument at the county level by considering the volatility of local employment and wages, as well as the concentration of economic activity in both importcompeting and high-skill, exporting sectors. We find, for the first time, that unemployment volatility influences U.S. presidential voting, as citizens are more likely to demonstrate their insecurity by voting against the incumbent. We confirm the Margalit (2011) finding that aggregate trade-related job losses decrease the incumbent vote share; and we demonstrate, as does Wright (2012), that unemployment is a partisan issue ‘owned’ by Democrats. Controlling for these factors along with job losses and employment volatility, we find evidence that the concentration of economic activity in low-wage tradable manufacturing diminishes the incumbent vote, while concentrations of employment in high-skill, exportable activities are associated with greater satisfaction with the incumbent.

The broader significance of our study is that it proposes and demonstrates that international trade influences U.S. presidential politics via an economic voting channel. The effects of rising import exposure, especially in low-skilled manufactured goods, appears to lessen incumbent party vote shares at both the national and county levels; the benefits of rising exports, in contrast, particularly in comparatively advantaged activities in the manufacturing and service sectors, appear to enhance incumbent party vote shares at both levels. Yet, because many of the swing states have high concentrations of low-skilled manufacturing, we find some evidence that Electoral College considerations provide an incentive to protect this sector. The extent to which 
the contestability of employment and economic insecurity from trade, rather than purely domestic economic concerns, shapes presidential election outcomes suggests a necessary coupling of previously isolated research streams in American politics and international political economy. 
TABLE 1 Base Models - Dependent Variable is National Incumbent Party (Two-Party) Vote Shares (1952-2012, 1936-2012)

\begin{tabular}{|c|c|c|c|c|c|c|c|c|c|}
\hline & Model 1 & Model 2 & Model 3 & Model 4 & Model 5 & Model 6 & Model 7 & $\begin{array}{l}\text { Model } 8 \\
(1936-)\end{array}$ & $\begin{array}{l}\text { Model } 9 \\
(1936-)\end{array}$ \\
\hline \multirow[t]{2}{*}{ Prior Incumbent Vote t-1 } & $-0.74 * * *$ & $-0.773 * * *$ & $-0.764 * * *$ & $-0.811^{* * *}$ & $-0.538 * * *$ & $-0.746 * * *$ & $-0.542 * * *$ & -0.443 & -0.441 \\
\hline & $(0.216)$ & $(0.155)$ & $(0.152)$ & $(0.06)$ & $(0.57)$ & $(0.122)$ & $(0.157)$ & $(0.255)$ & $(0.265)$ \\
\hline \multirow[t]{2}{*}{ Growth Q12_15 } & $0.022 * * *$ & $0.031^{* * *}$ & $0.032 * * *$ & $0.018^{* * *}$ & $0.021^{* * *}$ & $0.018^{* *}$ & $0.023 * * *$ & $0.018 * * *$ & $0.018^{* * *}$ \\
\hline & $(0.005)$ & $(0.004)$ & $(0.004)$ & $(0.005)$ & $(0.005)$ & $(0.006)$ & $(0.005)$ & $(0.004)$ & $((0.004)$ \\
\hline \multirow[t]{2}{*}{$\Delta$ TradeBal Q12_15 } & & $0.045^{* * *}$ & & $0.037 * * *$ & $0.032 * *$ & & & $0.026^{* *}$ & \\
\hline & & $(0.012)$ & & $(0.009)$ & $(0.012)$ & & & $(0.01)$ & \\
\hline \multirow[t]{2}{*}{$\Delta$ ImportsQ12_15 } & & & $-0.04 * *$ & & & $-0.036 * * *$ & $-0.028 * *$ & & $-0.025^{*}$ \\
\hline & & & $(0.013)$ & & & $(0.011)$ & $(0.012)$ & & $(0.015)$ \\
\hline \multirow[t]{2}{*}{$\Delta$ ExportsQ12_15 } & & & $0.06 * * *$ & & & $0.038 *$ & $0.044^{* *}$ & & $0.028 *$ \\
\hline & & & $(0.018)$ & & & $(0.019)$ & $(0.017)$ & & $(0.014)$ \\
\hline \multirow[t]{2}{*}{ BusSentimentQ15 } & & & & $0.0006^{* * *}$ & & $0.001 * *$ & & & \\
\hline & & & & $(0.0001)$ & & $(0.0002)$ & & & \\
\hline \multirow[t]{2}{*}{ July Gallup } & & & & & $0.0015^{* * *}$ & & $0.0014^{* *}$ & & \\
\hline & & & & & $(0.0006)$ & & $(0.0005)$ & & \\
\hline \multirow[t]{2}{*}{ War } & & & & & & & & 0.007 & 0.009 \\
\hline & & & & & & & & $(0.034)$ & $(0.02)$ \\
\hline \multirow[t]{2}{*}{ Constant } & $0.865 * * *$ & $0.869 * * *$ & $0.853^{* * *}$ & $0.818^{* * *}$ & $0.672 * * *$ & $0.817 * * *$ & $0.69 * * *$ & $0.722 * * *$ & $0.719 * * *$ \\
\hline & $(0.113)$ & $(0.081)$ & $(0.081)$ & $(0.03)$ & $(0.079)$ & $(0.069)$ & $(0.095)$ & $(0.139)$ & $(0.144)$ \\
\hline Obs. & 16 & 16 & 16 & 15 & 16 & 15 & 16 & 20 & 20 \\
\hline Adj. $R^{2}$ & 0.61 & 0.798 & 0.802 & 0.988 & 0.9 & 0.915 & 0.91 & 0.41 & 0.44 \\
\hline AR 1-2 test [p-value] & {$[0.87]$} & {$[0.37]$} & {$[0.94]$} & {$[0.37]$} & {$[0.94]$} & {$[0.42]$} & [0.92] & {$[0.25]$} & {$[0.28]$} \\
\hline ARCH 1-1 test [p-value] & {$[0.51]$} & {$[0.85]$} & {$[0.96]$} & {$[0.93]$} & {$[0.04 * *]$} & {$[0.98]$} & {$[0.16]$} & {$[0.93]$} & {$[0.99]$} \\
\hline Normality test [p-value]h & {$[0.85]$} & {$[0.53]$} & {$[0.85]$} & {$[0.84]$} & {$[0.87]$} & {$[0.85]$} & {$[0.88]$} & {$[0.40]$} & {$[0.38]$} \\
\hline
\end{tabular}


TABLE 2 County-level Determinants of Incumbent Two-Party Vote Shares, 1992-2012 Presidential Elections

\begin{tabular}{|c|c|c|c|c|c|}
\hline & (1) & (2) & (3) & $(4)$ & (5) \\
\hline & & Unweighted & Swing States & $\begin{array}{c}\text { Non-Swing } \\
\text { States }\end{array}$ & $\begin{array}{c}\text { Additional } \\
\text { Controls }\end{array}$ \\
\hline Unemployment & $\begin{array}{l}-0.0014^{* *} \\
(0.0068)\end{array}$ & $\begin{array}{l}-0.0022^{* * *} \\
(0.0037)\end{array}$ & $\begin{array}{l}-0.0046^{* * *} \\
(0.001)\end{array}$ & $\begin{array}{r}-0.0007 \\
(0.0008)\end{array}$ & $\begin{array}{l}-0.0015^{* *} \\
(0.0007)\end{array}$ \\
\hline Change in Unemployment (1-year) & $\begin{array}{r}-0.0017 \\
(0.0012)\end{array}$ & $\begin{array}{r}0.0004 \\
(0.0004)\end{array}$ & $\begin{array}{c}-0.0002 \\
(0.0011)\end{array}$ & $\begin{array}{r}-0.0021 \\
(0.0014)\end{array}$ & $\begin{array}{r}-0.0015 \\
(0.0011)\end{array}$ \\
\hline Unemployment Volatility & $\begin{array}{l}-0.0172 * * * \\
(0.0023)\end{array}$ & $\begin{array}{l}-0.0072 * * * \\
(0.0008)\end{array}$ & $\begin{array}{l}-0.0121^{* * *} \\
(0.002)\end{array}$ & $\begin{array}{l}-0.0182 * * * \\
(0.0027)\end{array}$ & $\begin{array}{l}-0.0174 * * * \\
(0.0021)\end{array}$ \\
\hline Average Pay & $\begin{array}{l}0.0137 \\
(0.014)\end{array}$ & $\begin{array}{l}-0.0155^{* *} \\
(0.0062)\end{array}$ & $\begin{array}{r}-0.0317 \\
(0.021)\end{array}$ & $\begin{array}{c}0.0284 * \\
(0.0157)\end{array}$ & $\begin{array}{r}0.0190 \\
(0.0144)\end{array}$ \\
\hline Change in Avg. Pay (1-year) & $\begin{array}{l}0.0992 * * * \\
(0.021)\end{array}$ & $\begin{array}{l}0.0065 \\
(0.011)\end{array}$ & $\begin{array}{r}0.0399 \\
(0.0352)\end{array}$ & $\begin{array}{l}0.1088^{* * *} \\
(0.0248)\end{array}$ & $\begin{array}{l}0.0915^{* * *} \\
(0.0206)\end{array}$ \\
\hline High-wage Tradable Manufacturing Empl. & $\begin{array}{l}0.0014^{* * *} \\
(0.0005)\end{array}$ & $\begin{array}{r}-0.0001 \\
(0.0003)\end{array}$ & $\begin{array}{r}-0.0038 \\
(0.0009)\end{array}$ & $\begin{array}{l}0.0019 * * * \\
(0.0006)\end{array}$ & $\begin{array}{l}0.0012^{* *} \\
(0.0005)\end{array}$ \\
\hline High-wage Tradable Service Empl. & $\begin{array}{l}0.0049 * * * \\
(0.0009)\end{array}$ & $\begin{array}{l}0.0019 * * * \\
(0.0005)\end{array}$ & $\begin{array}{r}0.0019 \\
(0.0014)\end{array}$ & $\begin{array}{l}0.0059 * * * \\
(0.001)\end{array}$ & $\begin{array}{l}0.0048^{* * *} \\
(0.0009)\end{array}$ \\
\hline Low-wage Tradable Manufacturing Empl. & $\begin{array}{l}-0.0058^{* * *} \\
(0.0015)\end{array}$ & $\begin{array}{l}-0.0048 * * * \\
(0.0008)\end{array}$ & $\begin{array}{l}-0.0124^{* * *} \\
(0.0032)\end{array}$ & $\begin{array}{l}-0.0040 * * \\
(0.0016)\end{array}$ & $\begin{array}{l}-0.0062^{* * *} \\
(0.0014)\end{array}$ \\
\hline Low-wage Tradable Service Empl. & $\begin{array}{l}0.0073^{* * *} \\
(0.0015)\end{array}$ & $\begin{array}{l}0.0027^{* * *} \\
(0.0009)\end{array}$ & $\begin{array}{l}0.0073^{* * *} \\
(0.0027)\end{array}$ & $\begin{array}{l}0.0074^{* * *} \\
(0.0018)\end{array}$ & $\begin{array}{l}0.0064^{* * *} \\
(0.0015)\end{array}$ \\
\hline Retired & & & & & $\begin{array}{l}-0.1513^{* *} \\
(0.064)\end{array}$ \\
\hline Female & & & & & $\begin{array}{l}0.5222^{* * *} \\
(0.1413)\end{array}$ \\
\hline African American & & & & & $\begin{array}{r}0.0360 \\
(0.0395)\end{array}$ \\
\hline Hispanic Latino & & & & & $\begin{array}{c}-0.0182 \\
(0.0332)\end{array}$ \\
\hline Bachelor's Degree & & & & & $-0.1156 * *$ \\
\hline
\end{tabular}




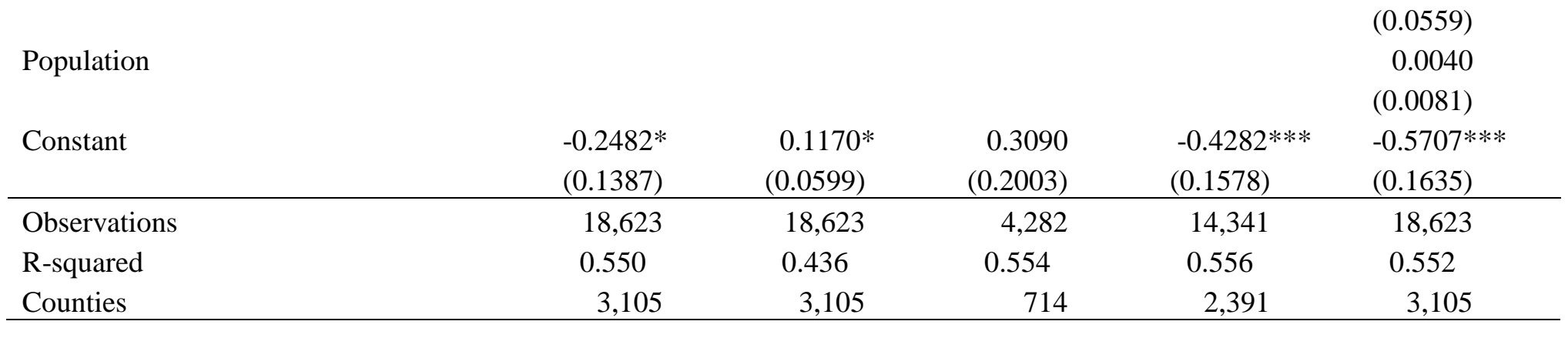

Note: The dependent variable is the change in the incumbent two-party vote share. All models include county and year fixed effects. The 10 swing states are

Colorado, Florida, Iowa, North Carolina, New Hampshire, Ohio, Pennsylvania, Virginia, Nevada, and Wisconsin. The trade exposure measures are log (relevant employment measure + 1) from the Census LBD. All estimates (except Column 2) are weighted by population size in 1990. The robust standard errors (reported in parentheses) are adjusted for clustering at the county level. ${ }^{*}$ p-value $<0.1 ;{ }^{* *}$ p-value $<0.05$; ${ }^{* * *}$ p-value $<0.01$. Source: confidential plant-level employment data from the U.S. Census Bureau. 


\section{REFERENCES}

Abramowitz, Alan I. 1988. “An Improved Model for Predicting Presidential-Election

Outcomes." Ps-Political Science \& Politics 21(4):843-7.

Abramowitz, Alan I. 2008. “It's about Time: Forecasting the 2008 Presidential Election with the Time-for-Change Model.” International Journal of Forecasting 24(2):209-17.

Antoniades, Alexis, and Charles W. Calomiris. 2014. "Mortgage Market Credit Conditions and U.S. Presidential Elections." Paper presented at the Mortara Political Economy Seminar Luncheon Series.

Autor, David H., David Dorn, and Gordon H. Hanson. 2013. “The China Syndrome: Local Labor Market Effects of Import Competition in the United States." American Economic Review 103(6):2121-68.

Bailey, Michael A., Judith Goldstein, and Barry R. Weingast. 1997. “The Institutional Roots of American Trade Policy.” World Politics 49(3):309-38.

Bernard, Andrew, J. Bradford Jensen and Peter K. Schott. 2006. "Survival of the Best Fit: Exposure to Low-Wage Countries and the (Uneven) Growth of U.S. Manufacturing Plants." Journal of International Economics 68:219-37.

Blinder, Alan S. and Alan B. Krueger. 2013. "Alternative Measures of Offshorability: A Survey Approach," Journal of Labor Economics, University of Chicago Press, vol. 31(S1), pages S97 - S12.

Broz, J. Lawrence. 2005. “Congressional Politics of International Financial Rescues.” American Journal of Political Science 49(3):479-96.

Broz, J. Lawrence, and Hawes, M. B. 2006. Congressional Politics of Financing the International Monetary Fund. International Organization 60(2):367-99. 
Campbell, James E. 2008. “Evaluating U.S. Presidential Election Forecasts and Forecasting Equations.” International Journal of Forecasting 24(2):257-69.

Campbell, James E., and Michael S. Lewis-Beck. 2008. “US Presidential Election Forecasting: An Introduction.” International Journal of Forecasting 24(2):189-92.

Erikson, Robert S. 1989. "Economic-Conditions and the Presidential Vote.” American Political Science Review 83(2):567-73.

Erikson, Robert S. 2009. "The American Voter and the Economy, 2008.” Ps-Political Science \& Politics 42(3):467-71.

Erikson, Robert S., Michael B. MacKuen, and James A. Stimson. 2002. The Macro Polity. New York: Cambridge University Press.

Fair, Ray C. 1978. "Effect of Economic Events on Votes for President." Review of Economics and Statistics 60(2):159-73.

Fair, Ray C. 2009. "Presidential and Congressional Vote-Share Equations.” American Journal of Political Science 53(1):55-72.

Feigenbaum, James J. and Andrew B. Hall. 2015. “How Legislators Respond to Localized Economic Shocks: Evidence from Chinese Import Competition.” Journal of Politics 77(4):1012-30.

Gervais, Antoine, and J. Bradford Jensen. 2013. "The Tradability of Services: Geographic Concentration and Trade Costs.” Boston: NBER Working Paper \#19759.

Goldstein, Judith. 1994. Ideas, Interests, and American Trade Policy. Ithaca, NY: Cornell University Press.

Grant, Taylor, and Matthew J. Lebo. Forthcoming. "Error Correction Methods with Political Time Series." Political Analysis. 
Hibbs, Douglas A., Jr. 2000. "Bread and Peace Voting in U.S. Presidential Elections.” Public Choice 104(1/2):149-80.

Hiscox, Michael J. 1999. “The Magic Bullet? The RTAA, Institutional Reform, and Trade Liberalization.” International Organization 53(4):669-98.

Hiscox, Michael J. 2002. Commerce, Coalitions, and Factor Mobility: Evidence from Congressional Votes on Trade Legislation. American Political Science Review 96(3):593-608.

Jarmin, R.S., and J. Miranda. 2002. The Longitudinal Business Database, <http://ideas.repec.org/s/cen/wpaper.html> Working paper 02-17, Center for Economic Studies, U.S. Census Bureau.

Jensen, J. Bradford. 2011. Global Trade in Services: Fear, Facts, and Offshoring. Washington, D.C.: Peterson Institute for International Economics.

Jensen, J. Bradford, and Lori G. Kletzer. 2006. "Tradable Services: Understanding the Scope and Impact of Services Offshoring.” In Brookings Trade Forum 2005, Offshoring WhiteCollar Work, eds. Susan M. Collins and Lael Brainard. Washington, DC: Brookings Institution, 75-134.

Jensen, J. Bradford, and Lori G. Kletzer. 2010. "Measuring Tradable Services and the Task Content of Offshorable Services Jobs." In Labor in the New Economy, eds. Katharine Abraham, Mike Harper and James Spletzer. Chicago: University of Chicago Press. Jensen, J. Bradford, Dennis P. Quinn, and Stephen Weymouth. 2015. “The Influence of Firm Global Supply Chains and Foreign Currency Undervaluations on U.S. Trade Disputes.” International Organization 69(4):913-47. 
Jensen, Nathan M. 2013. Domestic Institutions and the Taxing of Multinational Corporations. International Studies Quarterly 57(3): 440-448.

Kayser, Mark A., and Arndt Leininger. 2015. "Vintage Errors: Do Real-Time Economic Data Improve Election Forecasts?” Research and Politics. DOI: 10.1177/2053168015589624.

Kim, J. O., \& Mueller, C. W. 1978. Factor Analysis: Statistical Methods and Practical Issues. Newbury Park, CA: Sage Publications

Krueger, Alan B., and Lawrence H. Summers. 1988. "Efficiency Wages and the Inter-Industry Wage Structure.” Econometrica 56(2):259-93.

Leamer, Edward E. 2007. “A Flat World, a Level Playing Field, a Small World After All, or None of the Above? A Review of Thomas L. Friedman's The World is Flat." Journal of Economic Literature 45(March):83-126.

Lewis-Beck, Michael S., and Richard Nadeau. 2011. "Economic Voting Theory: Testing New Dimensions." Electoral Studies 30(2):288-94.

Lewis-Beck, Michael S., and Mary Stegmaier. 2000. "Economic Determinants of Electoral Outcomes.” Annual Review of Political Science 3:183-219.

Lewis-Beck, Michael S. and Charles Tien. 2004. "Jobs and the Job of the President: A Forecast for 2004.” PS: Political Science and Politics 37(4):753-758.

Lewis-Beck, Michael S., and Charles Tien. 2008. "Forecasting Presidential Elections: When to Change the Model.” International Journal of Forecasting 24(2):227-36.

Mansfield, Edward D. and Diana C. Mutz. 2013. "US versus Them: Mass Attitudes toward Offshore Outsourcing." World Politics 65(4):571-608.

Margalit, Yotam. 2011. “Costly Jobs: Trade-Related Layoffs, Government Compensation, and Voting in U.S. Elections.” American Political Science Review 105(1):166-88. 
Milner, Helen. 1988. “Trading Places: Industries for Free Trade.” World Politics 40(3):350-76.

Milner, Helen V., and Tingley, Dustin H. 2011. “Who Supports Global Economic Engagement? The Sources of Preferences in American Foreign Economic Policy.” International Organization 65(1):37-68.

Owen, Erica. 2015. "Exposure to Offshoring and the Politics of Trade Liberalization: Debates and Votes on Free Trade in the $108^{\text {th }}$ Congress.” Paper Presented at the 2015 American Political Science Association Convention, August 2015, San Francisco, CA.

Powell, G. Bingham, and Guy D. Whitten. 1993. “A Cross-National Analysis of Economic Voting - Taking Account of the Political Context.” American Journal of Political Science 37(2):391-414.

Quinn, Dennis P., and John T. Woolley. 2001. “Democracy and National Economic Performance: The Preference for Stability.” American Journal of Political Science 45(July):634-57.

Rickard, Stephanie J. 2015. “Compensating the Losers: An Examination of Congressional Votes on Trade Adjustment Assistance." International Interactions 41(1):46-60.

Rogowski, Ronald. 1987. Political Cleavages and Changing Exposure to Trade. American Political Science Review 81(December):1121-37.

Scheve, Kenneth, and Matthew J. Slaughter. 2004. "Economic Insecurity and the Globalization of Production." American Journal of Political Science 48(October):662-74.

Tufte, Edward R. 1978. Political Control of the Economy. Princeton, NJ: Princeton University Press.

Walter, Stephanie. 2010. "Globalization and the Welfare State: Testing the Microfoundations of the Compensation Hypothesis.” International Studies Quarterly 54(2):403-26. 
Wright, John R. 2012. "Unemployment and the Democratic Electoral Advantage.” American Political Science Review 106(4):685-702. 


\section{Appendix A}

\section{Correlations and Descriptive Statistics}

The pairwise correlations among the dependent and independent macro variables are presented in Appendix Tables A1. The descriptive statistics are reported in Tables A2a and A2b (macro and county level, respectively).

\section{Factor Analysis}

Factor analysis examines the intercorrelations among the variables and assesses whether an underlying or latent variable nests the explanatory variables.

At the macro level, the principal factor analysis shows that three latent variables undergird the macro data, accounting for $85 \%$ of the variance in the data. Business Sentiment Q15, July Gallup Presidential Approval, change in unemployment, economic growth, and change in exports all load strongly on the first factor. ${ }^{42}$ Two variables (change in consumer prices and job growth: $\triangle J o b s$ ) load on multiple dimensions. Incumbent Party terms and Incumbent Prior votes load on separate factors. Only $\triangle I m p o r t s / G D P$ fails to load on a factor: it consequently has a high uniqueness score. ${ }^{43}$

\footnotetext{
${ }^{42}$ As noted above, Campbell (2008) used the Gallup polls in early September of the election year instead of the July Gallup; Abramowitz (2008) used "net candidate advantage" derived from the June Gallup poll. Both variables load on the same first factor as July Gallup and other variables listed above.

43 "Uniqueness" refers to the information overlap between and among variables. In principal component analysis, the assumption is that variables have a high 'communality' of information.
} 
By contrast, the intercorrelations among the county-level variables are modest. Only underlying factor is present (which is correlated with income). All other variables have high uniqueness scores, suggesting that the information overlap among them is very low.

Principal factor analysis, used here, tests that assumption. The higher the $0-1$ 'unique' score, the more the variable is measuring a phenomenon different from that measured by other variables. Scores above 0.6 are considered to be 'high' and a sign that the variable is a reliably different measure from other variables. 
TABLE A1 Pairwise Correlations among the Dependent and Publicly Available Independent Variables (Macro Data)

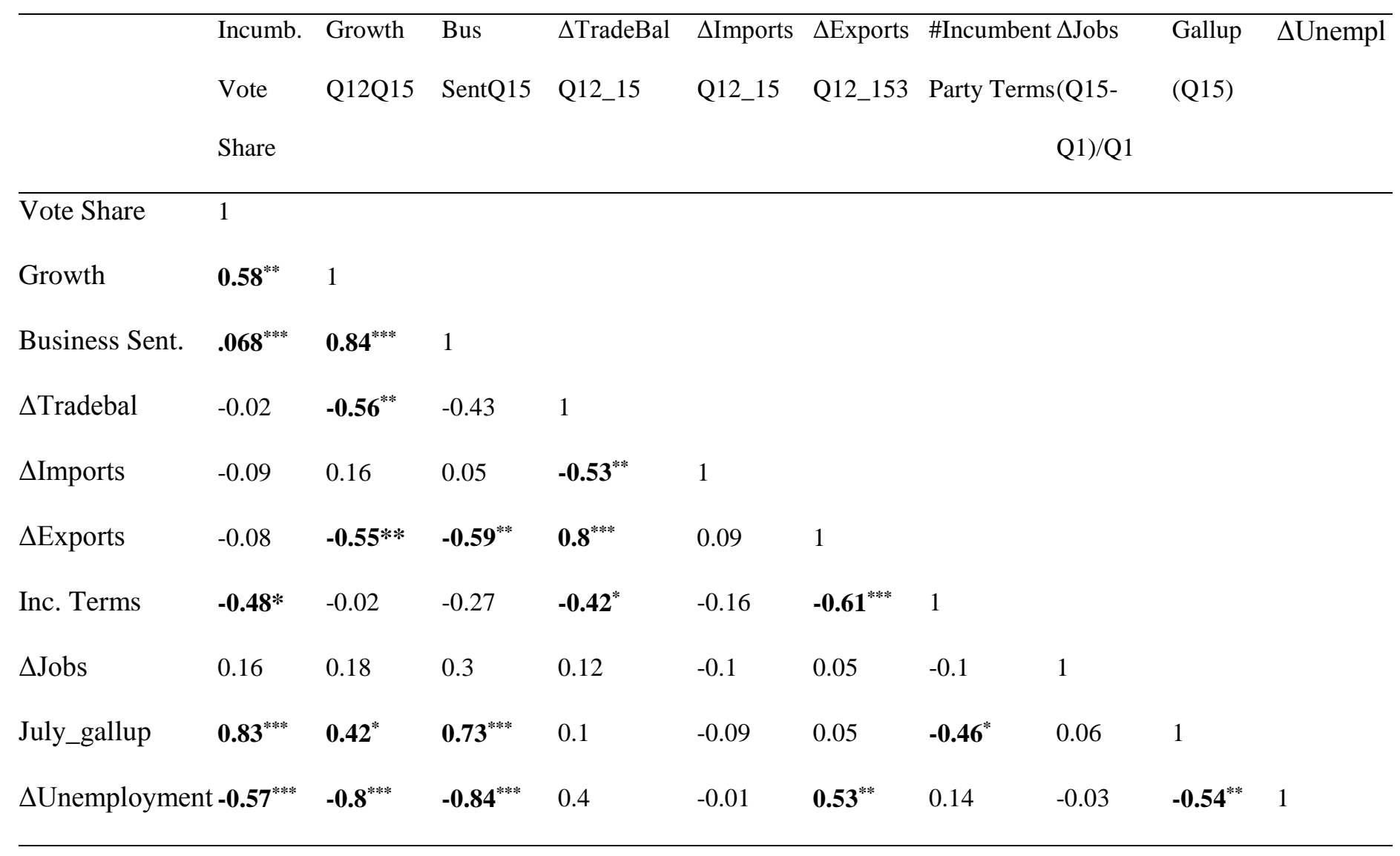


TABLE A2a Descriptive Statistics - Macro Level

\begin{tabular}{lccc}
\hline & Mean & Std. Deviation & N \\
\hline Vote Share & 0.52 & 0.06 & 16 \\
Growth Q12_Q15 & 2.08 & 2.44 & 16 \\
Business Sent. Q15 & 103.3 & 37.9 & 16 \\
$\Delta$ Tradebal Q12_Q15 & -0.12 & 0.63 & 16 \\
$\Delta$ Imports Q12_Q15 & 0.48 & 0.52 & 16 \\
$\Delta$ Exports Q12_Q15 & 0.32 & 0.47 & 16 \\
Inc. Terms & 1.81 & 1.28 & 16 \\
$\Delta$ Jobs (Q15-Q1)/Q15 & 8.59 & 2.99 & 16 \\
July_gallup Q15 & 47.6 & 14.17 & 16 \\
$\Delta$ Unemployment & -0.28 & 0.81 & \\
\hline
\end{tabular}


TABLE A2b Descriptive Statistics - County Level

\begin{tabular}{llcccc}
\hline & & & Std. & & \\
Variable & Obs & Mean & Dev. & Min & Max \\
\hline$\Delta$ Incumbent Two-Party Vote Share & 18,678 & -0.031 & 0.056 & -0.345 & 0.199 \\
Unemployment & 18,675 & 6.137 & 2.797 & 0.800 & 35.600 \\
Change in Unemployment (1-year) & 18,675 & -0.068 & 1.211 & -13.900 & 12.700 \\
Unemployment Volatility & 18,674 & 0.805 & 0.607 & 0.000 & 8.791 \\
Average Pay & 18,674 & 9.838 & 0.207 & 8.966 & 11.025 \\
Change in Avg. Pay (1-year) & 18,673 & 0.006 & 0.036 & -1.762 & 0.688 \\
Tradable Services Concentration & 18,260 & 0.619 & 0.347 & 0.000 & 6.893 \\
Manufacturing Concentration & 16,177 & 1.374 & 0.938 & 0.000 & 7.440 \\
\hline
\end{tabular}


TABLE A3a Factor Analysis, Macro, National Data

VARIABLE

Bus Sentiment Q15

$\Delta$ Unemployment

Growth Q12-Q15

July Gallup Approval

$\Delta$ Exports

CPI

Incumbent Prior Votes

$\Delta$ Jobs

Incumbent Party Terms

$\Delta$ Imports

\begin{tabular}{llll}
\hline \hline \multicolumn{3}{c}{ Component } \\
\hline 1 & 2 & 3 & Uniqueness \\
\hline 0.95 & & & 0.06 \\
-0.89 & & & 0.20 \\
0.87 & & & 0.16 \\
0.74 & & & 0.18 \\
-0.67 & & & 0.46 \\
-0.54 & 0.52 & 0.56 & 0.13 \\
& 0.84 & & 0.15 \\
& 0.57 & 0.56 & 0.32 \\
& & -0.66 & 0.31 \\
& & & 0.95
\end{tabular}

\begin{tabular}{lccc}
\hline \hline TS Squared & & & \\
Loadings & 3.89 & 1.88 & 1.32 \\
& & & \\
\hline \hline \% of Total Variance & 47 & 23 & 16 \\
\hline \hline Cumulative \% of & 47 & 69 & 85 \\
Variance & & & \\
\hline \hline
\end{tabular}

Notes: Number of observations $=15$. Unrotated matrix with Eigenvalues $>1.00$. Principal factor analysis is used. The factor loading scores represent the correlation between the variable and the factor. Factor loading scores below 0.5 are considered substantively insignificant, and thus are omitted. The square of the factor loading score is the size of the variable's total variance represented by the factor. For example, Business Sentiment Q15 loads roughly 90\% on Factor 1. 
TABLE A4 Alternative Measures of Trade, Incumbency, Growth, Sentiment, and Trade (Macro Models, 1952-2012)

\begin{tabular}{|c|c|c|c|c|c|c|c|c|}
\hline & Model 1 & Model 2 & $\begin{array}{l}\text { Model } 3 \\
\text { Man. Jobs }\end{array}$ & Model 4 & Model 5 & Model 6 & $\begin{array}{l}\text { Model } 7 \\
\text { Goods }\end{array}$ & $\begin{array}{l}\text { Model } 8 \\
\text { Services }\end{array}$ \\
\hline \multirow[t]{2}{*}{ Prior Incumbent Vote $\mathrm{t}-1$} & $-0.673 * * *$ & $-0.831 * *$ & $-0.619 * *$ & $-0.745 * * *$ & $-0.746 * * *$ & $-0.752 * * *$ & $-0.774 * * *$ & $-0.876^{* * *}$ \\
\hline & $(0.15)$ & $(0.163)$ & $(0.15)$ & $(0.159)$ & $(0.169)$ & $(0.015)$ & $(0.15)$ & $(0.204)$ \\
\hline \multirow[t]{2}{*}{ Growth Q12_15 } & $0.027 * * *$ & $0.031^{* * *}$ & $0.019 * * *$ & $0.029 * * *$ & $0.032 * * *$ & $0.032 * * *$ & $0.033^{* * *}$ & $0.024 * * *$ \\
\hline & $(0.005)$ & $(0.004)$ & $(0.007)$ & $(0.006)$ & $(0.004)$ & $(0.004)$ & $(0.004)$ & $(0.005)$ \\
\hline \multirow[t]{2}{*}{$\Delta$ ImportsQ12_15 } & $-0.039 * * *$ & $-0.037 * *$ & $-0.037 * * *$ & $-0.038^{* * *}$ & $-0.038 * *$ & $-0.034^{* *}$ & $-0.045^{* *}$ & $-0.176^{* *}$ \\
\hline & $(0.012)$ & $(0.014)$ & $(0.012)$ & $(0.014)$ & $(0.015)$ & $(0.014)$ & $(0.015)$ & $(0.078)$ \\
\hline \multirow[t]{2}{*}{$\Delta$ ExportsQ12_15 } & $0.038 *$ & $0.053^{* *}$ & $0.062 * * *$ & $0.061^{* * *}$ & $0.061^{* * *}$ & $0.064^{* * *}$ & $0.078 * * *$ & 0.098 \\
\hline & $(0.021)$ & $(0.019)$ & $(0.015)$ & $(0.019)$ & $(0.019)$ & $(0.018)$ & $(0.021)$ & $(0.103)$ \\
\hline \multirow[t]{2}{*}{ \#Incumbent Party Terms } & -0.011 & & & & & & & \\
\hline & $(0.006)$ & & & & & & & \\
\hline \multirow[t]{2}{*}{$\Delta$ Jobs (Q15-Q1)/Q1 } & & 0.003 & $0.008 * * *$ & & & & & \\
\hline & & $(0.002)$ & $(0.002)$ & & & & & \\
\hline \multirow[t]{2}{*}{$\Delta$ Unemployment } & & & & -0.011 & & & & \\
\hline & & & & $(0.014)$ & & & & \\
\hline \multirow[t]{2}{*}{ Inflation (CPI) } & & & & & -0.001 & & & \\
\hline & & & & & $(0.003)$ & & & \\
\hline \multirow[t]{2}{*}{ Time Trend } & & & & & & -0.002 & & \\
\hline & & & & & & $(0.002)$ & & \\
\hline \multirow[t]{2}{*}{ Constant } & $0.843^{* * *}$ & $0.868 * * *$ & $0.804 * * *$ & $0.848 * * *$ & $0.847 * * *$ & $0.486 * * *$ & $0.858 * * *$ & $0.936 * * *$ \\
\hline & $(0.076)$ & $(0.081)$ & $(0.074)$ & $(0.083)$ & $(0.087)$ & $(0.024)$ & $(0.079)$ & $(0.103)$ \\
\hline Obs. & 16 & 16 & 16 & 16 & 16 & 16 & 16 & 16 \\
\hline Adj. $R^{2}$ & 0.83 & 0.81 & 0.85 & 0.79 & 0.78 & 0.81 & 0.81 & 0.68 \\
\hline \multirow{2}{*}{$\begin{array}{l}\text { AR 1-2 test [p-value] } \\
\text { ARCH 1-1 test [p-value] }\end{array}$} & {$[0.85]$} & {$[0.67]$} & {$[0.54]$} & {$[0.96]$} & {$[0.72]$} & {$[0.6]$} & {$[0.81]$} & {$[0.78]$} \\
\hline & {$[0.13]$} & {$[0.55]$} & {$[0.88]$} & {$[0.42]$} & {$[0.65]$} & {$[0.76]$} & {$[0.65]$} & {$[0.96]$} \\
\hline Normality test [p-value] & {$[0.82]$} & {$[0.56]$} & {$[0.27]$} & {$[0.66]$} & {$[0.64]$} & {$[0.18]$} & {$[0.34]$} & {$[0.03]^{* *}$} \\
\hline
\end{tabular}




\section{Appendix B: Examining Alternative Hypotheses}

\section{Trade Adjustment Assistance (TAA)}

In Table B.1, we estimate models that include the numbers of workers filing for TAA, which Margalit showed were negatively associated with changes in the incumbent's (George W. Bush) vote share between 2000 and 2004. TAA filings are measured as the number of workers filing for TAA in the 4 years leading up to and including the election year (as a share of the total workforce). Our models include all presidential elections between 1996 and 2012. The results confirm Margalit's finding over the longer period of our study: TAA is associated with decreases in incumbent vote shares. In Column B.1, following Margalit, we model the change in incumbent vote shares, and include state (rather than county) fixed effects. Model 2 includes county fixed effects and county-level clustering, and the negative coefficient corresponding to TAA workers remains negative and statistically significant at the $90 \%$ level. We find that aggregate job losses associated with globalization, as captured by the TAA variable, reduce incumbent vote share, consistent with Margalit (2011). In Column 3 of Table B1, we include all our measures of county-level economic conditions; TAA Workers retains a negative coefficient, but is no longer statistically significant.

The remaining columns incorporate our measures of trade exposure from the census data.

Our results are broadly consistent with those reported in the paper. Low-wage tradable manufacturing is strongly associated with lower vote shares in swing states, while high-wage tradable services and manufacturing are strongly associated with increased vote shares in nonswing states. 


\section{TABLE B1 County-level Determinants of Incumbent Two-Party Vote Shares (1996-2012 Presidential Elections)}

\begin{tabular}{|c|c|c|c|c|c|c|}
\hline & State FE & County FE & County FE & $\begin{array}{c}\text { Include } \\
\text { Census } \\
\text { Contestability } \\
\text { Measures } \\
\end{array}$ & Swing States & $\begin{array}{l}\text { Non-Swing } \\
\text { States }\end{array}$ \\
\hline TAA Covered & $\begin{array}{c}-0.092 * * \\
(0.043)\end{array}$ & $\begin{array}{l}-0.074^{*} \\
(0.041)\end{array}$ & $\begin{array}{l}-0.059 \\
(0.041)\end{array}$ & $\begin{array}{l}-0.053 \\
(0.041)\end{array}$ & $\begin{array}{c}0.062 \\
(0.076)\end{array}$ & $\begin{array}{l}-0.088^{*} \\
(0.045)\end{array}$ \\
\hline Unemployment & $\begin{array}{l}0.001 * \\
(0.001)\end{array}$ & $\begin{array}{l}-0.001^{*} \\
(0.001)\end{array}$ & $\begin{array}{l}-0.000 \\
(0.001)\end{array}$ & $\begin{array}{l}0.000 \\
(0.001)\end{array}$ & $\begin{array}{l}-0.002 * * \\
(0.001)\end{array}$ & $\begin{array}{c}0.000 \\
(0.001)\end{array}$ \\
\hline Average Pay & $\begin{array}{l}0.018 * * * \\
(0.004)\end{array}$ & $\begin{array}{l}0.057 * * * \\
(0.014)\end{array}$ & $\begin{array}{c}0.022 \\
(0.015)\end{array}$ & $\begin{array}{l}0.015 \\
(0.015)\end{array}$ & $\begin{array}{l}-0.063 * * * \\
(0.023)\end{array}$ & $\begin{array}{l}0.037 * * \\
(0.017)\end{array}$ \\
\hline Change in Unemployment (1-year) & & & $\begin{array}{l}-0.001 \\
(0.001)\end{array}$ & $\begin{array}{l}-0.001 \\
(0.001)\end{array}$ & $\begin{array}{l}0.003^{* *} \\
(0.001)\end{array}$ & $\begin{array}{l}-0.003^{*} \\
(0.001)\end{array}$ \\
\hline Unemployment Volatility & & & $\begin{array}{l}-0.014 * * * \\
(0.002)\end{array}$ & $\begin{array}{l}-0.014 * * * \\
(0.002)\end{array}$ & $\begin{array}{l}-0.009 * * * \\
(0.002)\end{array}$ & $\begin{array}{l}-0.015^{* * *} \\
(0.002)\end{array}$ \\
\hline Change in Avg. Pay (1-year) & & & $\begin{array}{l}0.161^{* * *} \\
(0.030)\end{array}$ & $\begin{array}{l}0.155^{* * *} \\
(0.029)\end{array}$ & $\begin{array}{l}0.152^{* * *} \\
(0.044)\end{array}$ & $\begin{array}{l}0.154^{* * *} \\
(0.034)\end{array}$ \\
\hline $\begin{array}{l}\text { High-wage Tradable Manufacturing } \\
\text { Empl. }\end{array}$ & & & & $\begin{array}{l}0.003 * * * \\
(0.001)\end{array}$ & $\begin{array}{c}0.001 \\
(0.001)\end{array}$ & $\begin{array}{l}0.004^{* * *} \\
(0.001)\end{array}$ \\
\hline High-wage Tradable Service Empl. & & & & $\begin{array}{l}0.007 * * * \\
(0.001)\end{array}$ & $\begin{array}{c}0.0004 \\
(0.0004)\end{array}$ & $\begin{array}{l}0.009 * * * \\
(0.001)\end{array}$ \\
\hline Low-wage Tradable Manufacturing Empl. & & & & $\begin{array}{l}0.001 \\
(0.002)\end{array}$ & $\begin{array}{l}-0.008 * * * \\
(0.003)\end{array}$ & $\begin{array}{r}0.004^{*} \\
(0.002)\end{array}$ \\
\hline Low-wage Tradable Service Empl. & & & & $\begin{array}{l}0.009 * * * \\
(0.002)\end{array}$ & $\begin{array}{c}0.000 \\
(0.003)\end{array}$ & $\begin{array}{l}0.012 * * * \\
(0.002)\end{array}$ \\
\hline Constant & & & & $\begin{array}{l}-0.291 \\
(0.151)\end{array}$ & $\begin{array}{l}0.711^{* * *} \\
(0.218)\end{array}$ & $\begin{array}{l}-0.590 * * * \\
(0.175)\end{array}$ \\
\hline Observations & 15,554 & 15,554 & 15,553 & 15,519 & 3,569 & 11,950 \\
\hline R-squared & 0.485 & 0.456 & 0.474 & 0.483 & 0.500 & 0.491 \\
\hline
\end{tabular}


Note: The dependent variable is the change in the incumbent two-party vote share. The 1992 election is not included because TAA data are not available prior to 1994. TAA workers represents the total number of workers covered by TAA over the 4-year period including the 3 years prior to the election and the election year, as the share of total employed workers in the county in the election year. Estimates are weighted by population size in $1990{ }^{*} \mathrm{p}$-value $<0.1$; ${ }^{* *} \mathrm{p}$-value $<$ 0.05; *** p-value < 0.01. Source: Margalit 2011. 
Partisan Employment Effects. In Table B2, following Wright (2012), we allow for unemployment to exert differential effects on incumbent vote shares depending on the party of the incumbent. Our main results are little changed with this alternative specification; the estimated interaction effects are consistent with Wright (2012).

Table B2 County-level Determinants of Incumbent Two-Party Vote Shares (1992-2012 Presidential Elections)

\begin{tabular}{|c|c|c|c|c|}
\hline & (1) & $(2)$ & (3) & (4) \\
\hline & $\begin{array}{c}\text { Interact } \\
\text { Unemployment }\end{array}$ & $\begin{array}{c}\text { Interact Delta } \\
\text { Unemployment }\end{array}$ & Swing States & $\begin{array}{c}\text { Non-Swing } \\
\text { States }\end{array}$ \\
\hline Unemployment & $\begin{array}{l}-0.002 * * \\
(0.001)\end{array}$ & $\begin{array}{l}-0.002 * * \\
(0.001)\end{array}$ & $\begin{array}{l}-0.005^{* * *} \\
(0.001)\end{array}$ & $\begin{array}{r}-0.001 \\
(0.001)\end{array}$ \\
\hline Unemployment Volatility & $\begin{array}{l}-0.015^{* * *} \\
(0.002)\end{array}$ & $\begin{array}{l}-0.017^{* * *} \\
(0.002)\end{array}$ & $\begin{array}{l}-0.009 * * * \\
(0.002)\end{array}$ & $\begin{array}{l}-0.016^{* * *} \\
(0.003)\end{array}$ \\
\hline Average Pay & $\begin{array}{r}0.012 \\
(0.014)\end{array}$ & $\begin{array}{r}0.016 \\
(0.014)\end{array}$ & $\begin{array}{l}-0.036 * \\
(0.021)\end{array}$ & $\begin{array}{c}0.027 * \\
(0.016)\end{array}$ \\
\hline Change in Avg. Pay (1-year) & $\begin{array}{l}0.098^{* * *} \\
(0.021)\end{array}$ & $\begin{array}{l}0.101^{* * *} \\
(0.021)\end{array}$ & $\begin{array}{r}0.038 \\
(0.035)\end{array}$ & $\begin{array}{l}0.108^{* * *} \\
(0.025)\end{array}$ \\
\hline Change in Unemployment (1-year) & $\begin{array}{l}-0.004^{* * *} \\
(0.001)\end{array}$ & $\begin{array}{r}-0.001 \\
(0.001)\end{array}$ & $\begin{array}{l}-0.004 * * * \\
(0.001)\end{array}$ & $\begin{array}{l}-0.004^{* *} \\
(0.002)\end{array}$ \\
\hline Democratic Incumbent x Unemployment & & $\begin{array}{l}0.001^{*} \\
(.001)\end{array}$ & & \\
\hline Democratic Incumbent x Change in Unemployment (1-year) & $\begin{array}{l}0.005^{* * *} \\
(0.002)\end{array}$ & & $\begin{array}{l}0.007 * * * \\
(0.002)\end{array}$ & $\begin{array}{l}0.004^{* *} \\
(0.002)\end{array}$ \\
\hline High-wage Tradable Manufacturing Empl. & $\begin{array}{l}0.001^{* * *} \\
(0.001)\end{array}$ & $\begin{array}{l}0.001^{* * *} \\
(0.001)\end{array}$ & $\begin{array}{r}-0.004 \\
(0.001)\end{array}$ & $\begin{array}{l}0.002^{* * * *} \\
(0.001)\end{array}$ \\
\hline High-wage Tradable Service Empl. & $\begin{array}{l}0.005^{* * *} \\
(0.001)\end{array}$ & $\begin{array}{l}0.005^{* * *} \\
(0.001)\end{array}$ & $\begin{array}{r}0.002 \\
(0.001)\end{array}$ & $\begin{array}{l}0.006^{* * *} \\
(0.001)\end{array}$ \\
\hline Low-wage Tradable Manufacturing Empl. & $-0.006 * * *$ & $-0.006 * * *$ & $-0.013^{* * *}$ & $-0.004^{* *}$ \\
\hline
\end{tabular}




\begin{tabular}{lcccc} 
& $(0.001)$ & $(0.001)$ & $(0.003)$ & $(0.002)$ \\
Low-wage Tradable Service Empl. & $0.007^{* * *}$ & $0.007^{* * *}$ & $0.008^{* * *}$ & $0.008^{* * *}$ \\
& $(0.002)$ & $(0.002)$ & $(0.003)$ & $(0.002)$ \\
Constant & $-0.229^{* * *}$ & $-0.266^{*}$ & $0.344^{*}$ & $-0.413^{* * *}$ \\
& $(0.139)$ & $(0.138)$ & $(0.201)$ & $(0.158)$ \\
\hline Observations & 18623 & 18623 & 4282 & 14341 \\
R-squared & 0.551 & 0.5505 & 0.5556 & 0.5568 \\
Counties & 3105 & 3105 & 714 & 2391 \\
\hline
\end{tabular}

Note: We control for partisan employment effects. The dependent variable is the change in the incumbent two-party vote share. All models include county and year fixed effects. The Democratic incumbent dummy is collinear with the year fixed effects and omitted from the model. The 10 swing states are Colorado, Florida, Iowa, North Carolina, New Hampshire, Ohio, Pennsylvania, Virginia, Nevada, and Wisconsin. The trade exposure measures are log (relevant employment measure + 1) from the Census LBD. All estimates (except Column 2) are weighted by population size in 1990. The robust standard errors (reported in parentheses) are adjusted for clustering at the county level. * p-value $<0.1$; ** p-value $<0.05$; *** p-value $<0.01$. Source: Wright 2012. 
Employment in Exporting Firms. Column 1 reports the baseline specification with total manufacturing employment in the county and the employment at manufacturing exporters as the measure of trade exposure. When the measure of trade exposure is total employment at manufacturing exporters, the coefficient estimate is negative and statistically significant. In Column 2, we separate exporter employment into high- and low-wage establishments. While the coefficient estimate on high-wage manufacturing exporters is positive, it is not statistically significant. The coefficient estimate for low-wage manufacturing exporters is negative and statistically significant.

TABLE B3 County-level Determinants of Incumbent Two-Party Vote Shares (1992-2012)

\begin{tabular}{lll}
\hline & $(1)$ & $(2)$ \\
\hline Unemployment & $-0.002^{* *}$ & $-0.002^{* *}$ \\
Change in Unemployment (1-year) & $(0.001)$ & $(0.001)$ \\
& -0.002 & -0.002 \\
Unemployment Volatility & $(0.001)$ & $(0.001)$ \\
& $-0.017^{* * *}$ & $-0.017^{* * *}$ \\
Average Pay & $(0.002)$ & $(0.002)$ \\
& 0.021 & 0.020 \\
Change in Avg. Pay (1-year) & $(0.014)$ & $(0.014)$ \\
& $0.103^{* * *}$ & $0.103^{* * *}$ \\
Manufacturing Employment & $(0.021)$ & $(0.021)$ \\
& -0.002 & -0.003 \\
Employment at Manufacturing Exporters & $(0.002)$ & $(0.002)$ \\
Empl. At High-wage Manufacturing Exporters & $-0.002^{* * *}$ & \\
Empl. At Low-wage Manufacturing Exporters & $(0.001)$ & \\
Constant & & 0.000 \\
Counties & & $(0.0004)$ \\
Table reports alternative measures of trade exposure (employment & $-0.001^{*}$ \\
R-squared & & $(0.001)$ \\
& -0.205 \\
& & $(0.135)$ \\
\hline
\end{tabular}

Note: Table reports alternative measures of trade exposure (employment in exporting firms) 


\section{Appendix C: Replications of County-Level Results using Publicly Available Industry Data}

In this Appendix, we substitute the contestability measures derived from the confidential Census data with publicly available data from the BLS Quarterly Census of Employment and Wages. We capture the concentration of workers in different sectors using sectoral employment location quotients calculated by the BLS. A location quotient is a ratio used to compare the concentration of employment in different sectors among different counties. For instance, the manufacturing employment location quotient is the number of workers employed in manufacturing in county $i$ as the share of total workers in county $i$, as a ratio of the share of manufacturing workers to total workers in the United States.

The location quotients provide crude proxies for trade contestability. For instance, the employment location quotient of an industry in which the United States has a comparative advantage, such as business or other tradable services, will capture the concentration of workers that may gain from globalization in a particularly county. We are not able to precisely capture potential winners and losers within manufacturing using the publicly available data, however, since the manufacturing location quotients are not disaggregated below the one-digit level. (This is one of the major advantages of the census data - the ability to capture highly disaggregated industry variation in tradability within manufacturing and services. Taking the sector as a whole, our expectation is that manufacturing is largely contestable and (on average) a comparatively disadvantaged sector in the United States. We incorporate the employment location quotients of 
manufacturing and tradable services into our models to test our hypotheses about the differential economic voting responses of the losers and winners of globalization, respectively. ${ }^{44}$

Table C1 reports models of changes in incumbent two-party vote shares at the county level in presidential election years 1992 through 2012. Unless otherwise noted, all models include year and county fixed effects, and the standard errors are clustered at the county level.

The results in Column 1 indicate that voters respond in anticipated ways to changes in income and employment. Employment volatility decreases incumbent vote share, while increases in wages are associated with increasing support for the incumbent party. The coefficient estimate corresponding to Unemployment Volatility ${ }^{45}$ implies that a one-standard-deviation increase in unemployment volatility is associated with a $1 \%$ decrease in incumbent vote share. A onestandard-deviation increase in unemployment is associated with a $0.44 \%$ decrease in vote shares. An increase in average pay over the previous year ( $\Delta$ Average Pay (1-year)) equal to one standard deviation increases the incumbent vote share by $0.41 \%$.

\footnotetext{
${ }^{44}$ We classify tradable services at the two-digit industry by applying a location quotient cutoff of 0.6. According to our classification, tradable services include information, finance, and business and professional services. Nontradable services are trade, transportation and utilities, leisure and hospitality, education and healthcare, and other services. The BLS does not distinguish among manufacturing industries in reporting the manufacturing location quotients. See http://www.bls.gov/cew/datatoc.htm, accessed June 21, 2015.

${ }^{45}$ Unemployment volatility is measured as the standard deviation of the unemployment rate over the 4 years prior to and including the election year.
} 
Model 2 introduces the employment location quotients for manufacturing and tradable services. The location quotients measure the concentration of workers in each sector in each county-year.

With regard to manufacturing, the estimated coefficient implies that higher concentrations of manufacturing employment are associated with lower vote shares for the incumbent, even after controlling for income, unemployment, and employment volatility. A onestandard-deviation increase in the manufacturing location quotient is associated with a $0.89 \%$ decrease in the incumbent vote share.

In contrast, services employment—particularly high concentrations of employment in tradable services - are associated with increases in incumbent vote shares. A one-standarddeviation increase in the concentration of employment in tradable services is associated with a $0.33 \%$ increase in the incumbent vote share. We include the unweighted model estimates in Column 3. We note that the magnitude of the manufacturing coefficient increases over three times. Tradable services is not statistically differentiable from zero in the unweighted model.

The degree to which our framework can help explain the outcome of national-level presidential contests largely depends on whether our indicators of economic insecurity explain variation in incumbent vote shares in counties in the swing states. In Columns 3 and 4 of Table C1, we report coefficient estimates among the sample of swing and non-swing states, respectively. ${ }^{46}$ The results indicate that Unemployment Volatility is associated with lower

\footnotetext{
${ }^{46}$ To repeat, these are Colorado, Florida, Iowa, North Carolina, New Hampshire, Ohio, Pennsylvania, Virginia, Nevada, and Wisconsin ("The 10 Closet States in Election 2012," Washington Post, November 8, 2012.).
} 
incumbent vote shares in both swing and non-swing states, but the estimated coefficient is larger in the latter sample. Manufacturing Concentration is strongly negatively associated with changes in incumbent vote share in swing states. The estimated coefficient corresponding to

Manufacturing Concentration is over three times as large in the swing states as compared to our previous estimates using the full sample of counties (Model 2): a one-standard-deviation increase in manufacturing concentration is associated with a $2.5 \%$ decline in incumbent vote share in swing states. We find that higher levels of concentration of tradable services and higher levels of average income are associated with greater support for the incumbent in non-swing states. ${ }^{47}$ The estimated effect of a one-standard-deviation increase in tradable services is nearly 1.5 times as large in non-swing states compared to the full sample; in swing states, the coefficient is not statistically different from zero. These results, which we display graphically in Figure C2, are broadly consistent with those reported in the main text.

In Column 6 of Table C1, we include county-level demographic characteristics in our county fixed-effects model using the full sample, and the results are little changed.

47 The results are consistent when we analyze a smaller swing state sample, dropping Nevada and Wisconsin. 
Figure C1. Manufacturing and Service Sector

Correlation Between Education and Earnings, 2009

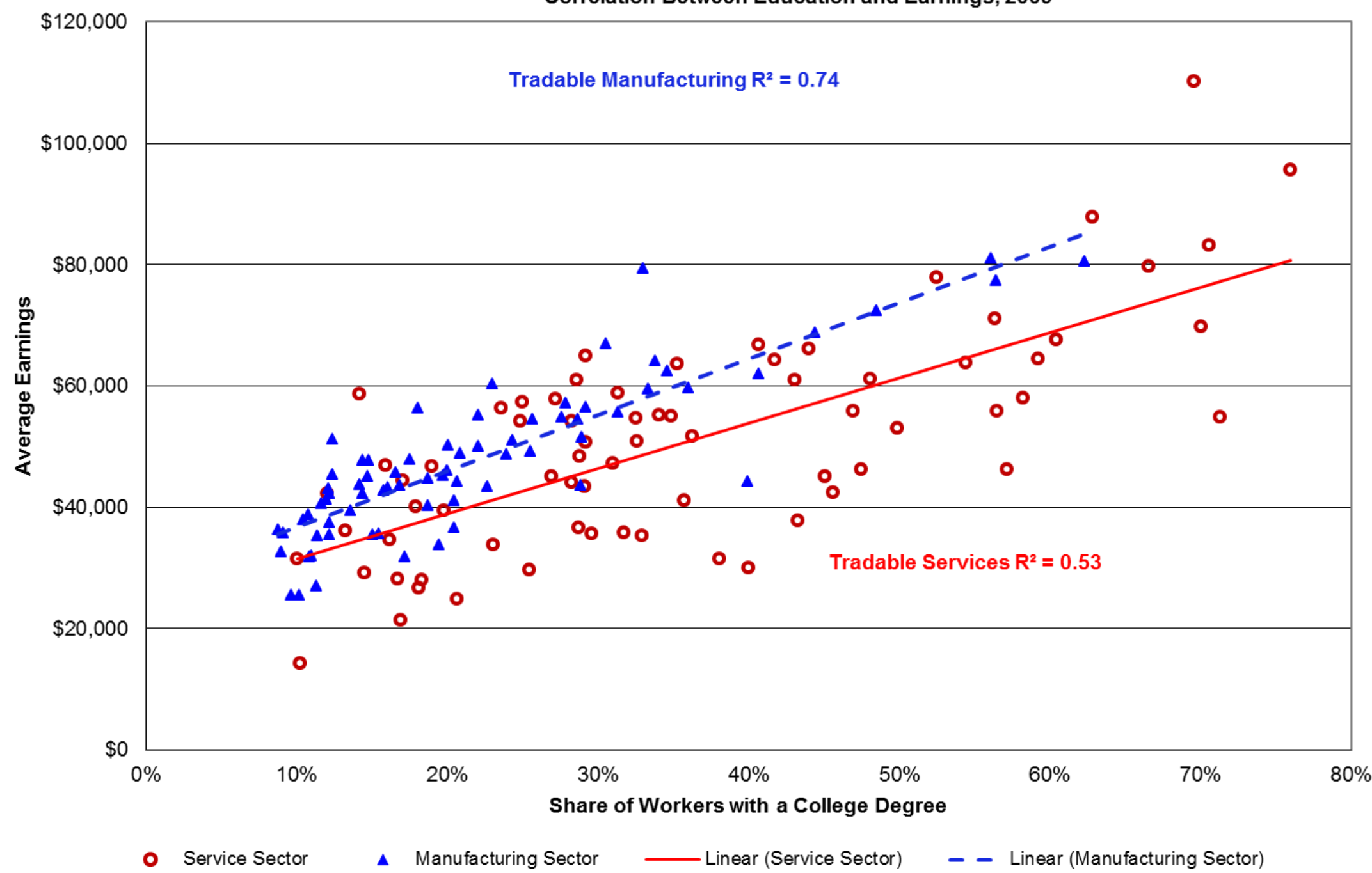




\section{FIGURE C.2 Marginal Effects (Based on Estimates in Table A1)}

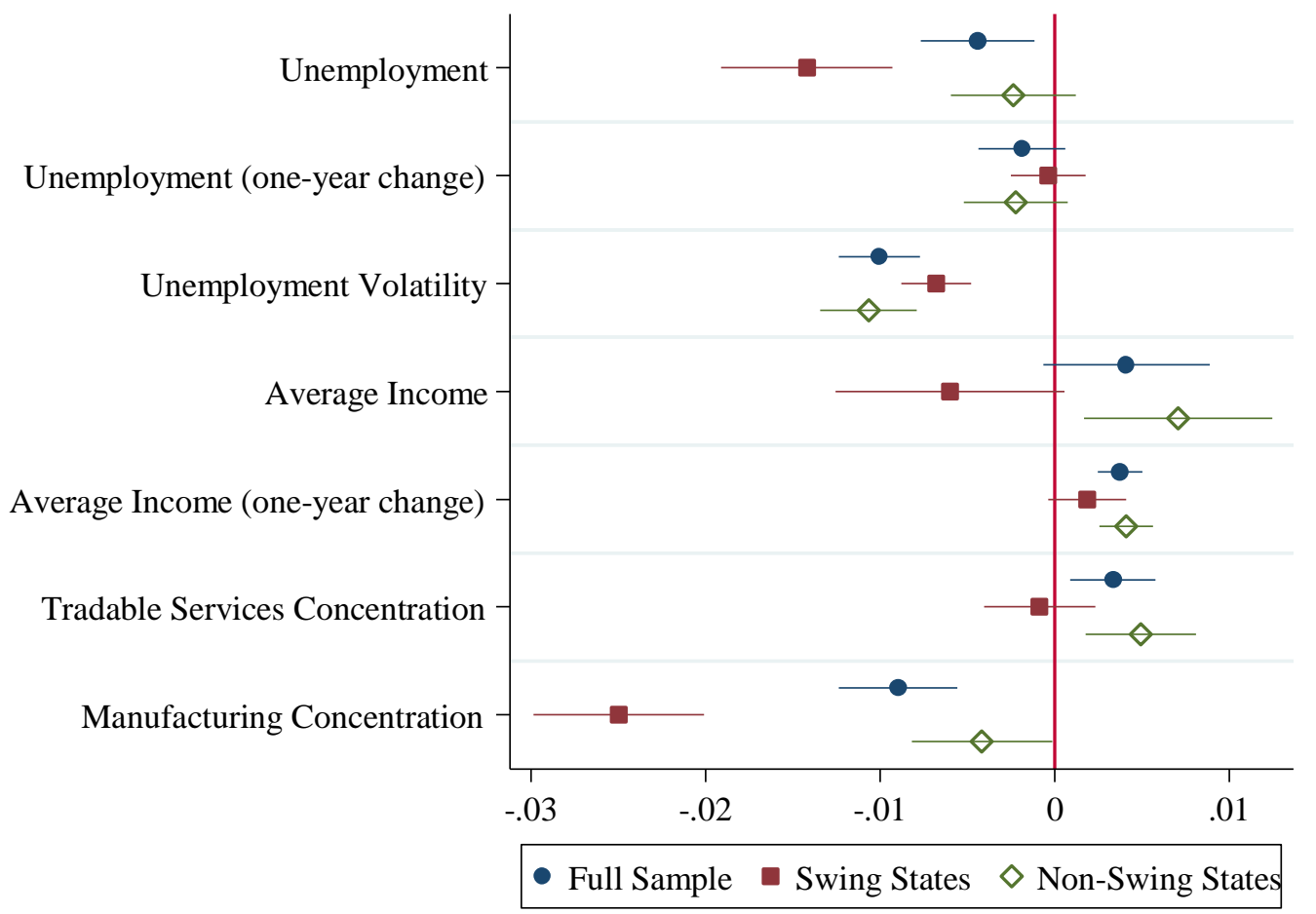

Note: The figure shows the estimated effect of a one-standard-deviation change in the explanatory variables on the incumbent vote share. The results are based on Models 2, 4, and 5 of Table A1, with regressors standardized to a mean of 0 and standard deviation of 1 . 
TABLE C1 County-level Determinants of Incumbent Two-Party Vote Shares (1992-2012 Presidential Elections)

\begin{tabular}{|c|c|c|c|c|c|c|}
\hline & (1) & (2) & (3) & $(4)$ & (5) & (6) \\
\hline & & & Unweighted & $\begin{array}{l}\text { Swing } \\
\text { States }\end{array}$ & $\begin{array}{c}\text { Non-swing } \\
\text { States }\end{array}$ & $\begin{array}{c}\text { Additiona } \\
\text { Controls }\end{array}$ \\
\hline Unemployment & $\begin{array}{c}-0.001 * * \\
(0.001)\end{array}$ & $\begin{array}{c}-0.002 * * \\
(0.001)\end{array}$ & $\begin{array}{c}-0.002^{* * *} \\
(0.000)\end{array}$ & $\begin{array}{c}-0.005^{* * *} \\
(0.001)\end{array}$ & $\begin{array}{l}-0.001 \\
(0.001)\end{array}$ & $\begin{array}{c}-0.002^{* *} \\
(0.001)\end{array}$ \\
\hline Change in Unemployment (1-year) & $\begin{array}{l}-0.002 \\
(0.001)\end{array}$ & $\begin{array}{l}-0.002 \\
(0.001)\end{array}$ & $\begin{array}{c}0.001 \\
(0.000)\end{array}$ & $\begin{array}{l}-0.000 \\
(0.001)\end{array}$ & $\begin{array}{l}-0.002 \\
(0.001)\end{array}$ & $\begin{array}{c}-0.001 \\
(0.001)\end{array}$ \\
\hline Unemployment Volatility & $\begin{array}{c}-0.017 * * * \\
(0.002)\end{array}$ & $\begin{array}{c}-0.017 * * * \\
(0.002)\end{array}$ & $\begin{array}{c}-0.007 * * * \\
(0.001)\end{array}$ & $\begin{array}{c}-0.011^{* * *} \\
(0.002)\end{array}$ & $\begin{array}{c}-0.018 * * * \\
(0.003)\end{array}$ & $\begin{array}{c}-0.017 * * * \\
(0.002)\end{array}$ \\
\hline Average Pay & $\begin{array}{c}0.019 \\
(0.014)\end{array}$ & $\begin{array}{c}0.020 \\
(0.014)\end{array}$ & $\begin{array}{c}-0.018 * * \\
(0.008)\end{array}$ & $\begin{array}{l}-0.029 \\
(0.019)\end{array}$ & $\begin{array}{c}0.034^{* *} \\
(0.016)\end{array}$ & $\begin{array}{c}0.029 * * \\
(0.015)\end{array}$ \\
\hline Change in Avg. Pay (1-year) & $\begin{array}{c}0.101^{* * *} \\
(0.021)\end{array}$ & $\begin{array}{c}0.104^{* * *} \\
(0.022)\end{array}$ & $\begin{array}{l}0.021^{*} \\
(0.011)\end{array}$ & $\begin{array}{c}0.052 \\
(0.037)\end{array}$ & $\begin{array}{c}0.114^{* * *} \\
(0.026)\end{array}$ & $\begin{array}{c}0.091^{* * *} \\
(0.021)\end{array}$ \\
\hline Tradable Services Concentration & & $\begin{array}{c}0.010 * * \\
(0.004)\end{array}$ & $\begin{array}{l}-0.001 \\
(0.002)\end{array}$ & $\begin{array}{l}-0.002 \\
(0.006)\end{array}$ & $\begin{array}{c}0.014^{* * *} \\
(0.006)\end{array}$ & $\begin{array}{c}0.010 * * \\
(0.004)\end{array}$ \\
\hline Manufacturing Concentration & & $\begin{array}{c}-0.010^{* * *} \\
(0.002)\end{array}$ & $\begin{array}{c}-0.012^{* * *} \\
(0.002)\end{array}$ & $\begin{array}{c}-0.027 * * * \\
(0.003)\end{array}$ & $\begin{array}{l}-0.004^{*} \\
(0.003)\end{array}$ & $\begin{array}{r}-0.010 * * * \\
(0.002)\end{array}$ \\
\hline Retired & & & & & & $\begin{array}{c}-0.180 * * * \\
(0.069)\end{array}$ \\
\hline Female & & & & & & $\begin{array}{c}0.598 * * * \\
(0.152)\end{array}$ \\
\hline African American & & & & & & $\begin{array}{c}0.030 \\
(0.039)\end{array}$ \\
\hline Hispanic Latino & & & & & & $\begin{array}{l}-0.046 \\
(0.034)\end{array}$ \\
\hline Bachelor's Degree & & & & & & $\begin{array}{c}-0.177^{* * *} \\
(0.057)\end{array}$ \\
\hline Population & & & & & & $\begin{array}{c}0.011 \\
(0.008)\end{array}$ \\
\hline
\end{tabular}




\begin{tabular}{lcccccc} 
Constant & $-0.230^{*}$ & $-0.240^{*}$ & $0.145^{* *}$ & 0.287 & $-0.395^{* *}$ & $-0.727^{* * *}$ \\
& $(0.135)$ & $(0.139)$ & $(0.072)$ & $(0.189)$ & $(0.158)$ & $(0.167)$ \\
\hline Observations & 18,663 & 16,135 & 16,135 & 3,947 & 12,188 & 16,135 \\
R-squared & 0.546 & 0.551 & 0.459 & 0.558 & 0.557 & 0.555 \\
Counties & 3,111 & 2,896 & 2,896 & 695 & 2,201 & 2,896 \\
\hline
\end{tabular}

Note: The dependent variable is the change in the incumbent two-party vote share. Democratic Party incumbent election years are 1996, 2008, and 2012; Republican Party incumbent election years are 1992, 2004, and 2008. All models include county and year fixed effects. Unemployment volatility is the standard deviation of the county-level unemployment rate calculated over the 4-year period including the 3 years prior to the election and the election year. All other regressors are also measured at the county level, and correspond to the election year. Average pay and the concentration measures enter as natural logs. The concentration measures are employment location quotients from the U.S. Quarterly Census of Employment and Wages and computed by the BLS. Tradable services include information, finance, and business and professional services. All estimates, except those appearing in Column 3, are weighted by population size in 1990. The robust standard errors (reported in parentheses) are adjusted for clustering at the county level. * p-value $<0.1 ; * *$ p-value $<0.05 ; * * *$ p-value $<0.01$. 
In this section, we further examine variation in the manufacturing sectors in swing and non-swing states. In particular, we are interested in uncovering potential sources of the large increase in the estimated coefficient corresponding to low-skilled manufacturing in swing states. We want to know if there are systematic differences in employment characteristics between swing and non-swing states. To conduct the analysis, we use the publicly available employment data from the BLS. We calculated the share of employment in manufacturing in swing and nonswing states between 1992 and 2012 to see if manufacturing makes up a larger, and thus potentially more politically salient, share of employment in swing states. Averaging over the period, we find that $12.9 \%$ of employment in swing states is in manufacturing, compared with $11.6 \%$ in the non-swing sample, a difference that is not statistically significant $(\mathrm{t}=-0.74)$. When we divide states according to the median manufacturing share of employment over the period, we find that 6 of the 10 swing states have manufacturing employment shares greater than the median (PA, OH, IA, NH, NC, WI).

The large magnitude of the low-skilled manufacturing coefficient in swing states appears to be driven by this sample of high-manufacturing swing states. The share of employment in manufacturing in these six manufacturing swing states is $16.9 \%$, compared with the $6.8 \%$ average manufacturing employment share in the other swing states (CO, FL, NV, VA). Appendix Table C2 reports estimates on subsamples using the publicly available BLS data on sectoral employment concentration in manufacturing and tradable services. When we constrain the sample to these six high-manufacturing swing states and estimate the model, we find a large and statistically significant coefficient estimate equal to -0.028 ; in the four non-manufacturing swing states, the coefficient estimate falls to -0.005 and is not statistically significant. In additional analyses reported in Table C2, the manufacturing concentration becomes statistically 
significant when we constrain the sample to high-manufacturing states (both swing and nonswing), but not for low-manufacturing states. We conclude that the apparent salience of manufacturing concentration in swing states is driven by the importance of manufacturing in the Northern swing states that have historically large manufacturing bases.

TABLE C2 County-level Determinants of Incumbent Two-Party Vote Shares (1992-2012 Presidential Elections)

\begin{tabular}{lcccc}
\hline & $(1)$ & $(2)$ & $(3)$ & $(4)$ \\
\hline & High-MNF & Low-MNF & & \\
& Swing & Swing & High-MNF & Low-MNF \\
& States & States & States & States \\
\hline Unemployment & $-0.004^{* * *}$ & $-0.004^{* * *}$ & $-0.005^{* * *}$ & -0.001 \\
& $(0.001)$ & $(0.001)$ & $(0.001)$ & $(0.001)$ \\
Change in Unemployment (1-year) & 0.001 & 0.002 & $0.002^{* *}$ & $-0.003^{*}$ \\
& $(0.002)$ & $(0.002)$ & $(0.001)$ & $(0.002)$ \\
Unemployment Volatility & $-0.014^{* * *}$ & $-0.008^{* *}$ & $-0.009 * * *$ & $-0.022^{* * *}$ \\
& $(0.003)$ & $(0.004)$ & $(0.001)$ & $(0.003)$ \\
Average Pay & $-0.061^{* *}$ & -0.010 & $-0.026^{*}$ & $0.068^{* * *}$ \\
& $(0.024)$ & $(0.024)$ & $(0.014)$ & $(0.019)$ \\
Change in Avg. Pay (1-year) & 0.070 & -0.032 & $0.101^{* * *}$ & $0.076^{* *}$ \\
Tradable Services Concentration & $(0.054)$ & $(0.048)$ & $(0.032)$ & $(0.032)$ \\
& -0.003 & -0.006 & 0.007 & 0.010 \\
Manufacturing Concentration & $(0.008)$ & $(0.005)$ & $(0.005)$ & $(0.008)$ \\
& $-0.028^{* * *}$ & -0.005 & $-0.016^{* * *}$ & -0.001 \\
Constant & $(0.004)$ & $(0.005)$ & $(0.002)$ & $(0.006)$ \\
& $0.614^{* * *}$ & 0.046 & $0.239^{*}$ & $-0.718^{* * *}$ \\
\hline Observations & $(0.235)$ & $(0.232)$ & $(0.135)$ & $(0.193)$ \\
R-squared & 2,567 & 1,380 & 9,998 & 6,137 \\
Counties & 0.498 & 0.704 & 0.516 & 0.599 \\
\hline
\end{tabular}

Note: The dependent variable is the change in the incumbent two-party vote share. All models include county and year fixed effects. Unemployment volatility is the standard deviation of the county-level unemployment rate calculated over the 4-year period including the 3 years prior to 
the election and the election year. All other regressors are also measured at the county level, and correspond to the election year. Average pay and the concentration measures enter as natural logs. The concentration measures are employment location quotients from the U.S. Quarterly Census of Employment and Wages and computed by the BLS. Tradable services include information, finance, and business and professional services. All estimates, except those appearing in Column 3, are weighted by population size in 1990. The robust standard errors (reported in parentheses) are adjusted for clustering at the county level. States are grouped as being high- and low- concentration manufacturing states according to the median share of employment in manufacturing averaged over the period 1992-2012. * p-value < 0.1; ** p-value $<0.05 ; * * *$ p-value $<0.01$ 


\section{Appendix D: Measures and Data Sources in National Models}

Economic Growth. Multiple measures of economic growth are used. Quarterly per capita real GDP growth is taken from the Bureau of Economic Analysis (BEA), Survey of Current Business. The growth rate from Q12 through Q15 is used, as is the growth rate in Q14 (following Abramowitz 2008). The results are not sensitive to the indicator of growth or its timing. Quarterly growth is available only from 1952 onward.

Exports and Imports. Exports and imports are measured as a percentage of GDP, Q12-Q15, both in levels and changes. The data come from the BEA, Survey of Current Business. The data prior to 1952 are also from the BEA, but are annual changes.

Consumer Sentiment and Business Conditions. The data from both series are taken from the University of Michigan/Reuters series. Historical data on consumer sentiment is also available from the St. Louis Federal Reserve (UMCSENT1 series) from late 1952 on. The Business Conditions series (used in Erikson 2009) is available from 1954 onward. ${ }^{48}$ The indicator on the closest date prior to the presidential election is used.

Inflation, Jobs, and Unemployment. The unemployment series is the unemployment rate of economically active individuals from the BEA website; the CPI is from the Bureau of Labor Statistics. 'Jobs' is the percentage change in numbers employed during a presidential term measured from January in Q1 to June of the election years, and is from Lewis-Beck and Tien (2004), with an update by the authors.

${ }^{48}$ In the University of Michigan survey, respondents are asked, "And how about a year from now, do you expect that in the country as a whole business conditions will be better, or worse than they are at present, or just about the same." The 'relative' score is used, which is (betterworse) +100 . 
July Gallup Poll and Net Candidate Advantage. July Gallup Poll is the presidential popularity in the first Gallup Poll in July of an election year, and is from Lewis-Beck and Tien (2008) (with an update by the authors). An alternative used in Abramowitz 2008 is to take the difference between the incumbent's favorable and unfavorable ratings. The empirical results are almost identical. Net Candidate Advantage is the incumbent candidate (or party) advantage from the American National Election Survey: items VCF0403, VCF0407, and VCF0409.

Number of Incumbent Terms. This indicator is the number of consecutive terms an incumbent party has controlled the presidency. The variable is suggested by Abramowitz $(1988,2008)$ and is also known as the Time for Change variable.

\section{Data Used in County-Level Models}

Incumbent vote shares. We construct the change in the two-party vote share of the incumbent party. Incumbent vote shares are incumbent party votes as a share of total Democratic and Republican votes. Source: Dave Leip's Atlas of U.S. Presidential Elections http://uselectionatlas.org/

Sectoral Employment Concentration. Location quotients compare the industrial activity levels among different counties. These are used in the analysis reported in Appendix C. Location quotients are ratios that compare the concentration of employment in a defined area (in this case, the county) to that of the entire country. We use the share of employment in the industry in county $i$ relative to the industry share of employment in the United States. Source: http://www.bls.gov/cew/datatoc.htm

Unemployment. County-level unemployment rate corresponds to the election year. Source: BLS http://www.bls.gov/lau/\#tables

Unemployment Volatility. The standard deviation of unemployment, measured over the 4-year period prior to and including the election year. Source: BLS http://www.bls.gov/lau/\#tables

Average Pay. The log of average pay of all workers during the election year. Source: BLS Quarterly Census of Employment and Wages http://www.bls.gov/cew/datatoc.htm 
Change in Average Pay. One-year change in the log of average pay between election year and the year prior to the election. Source: http://www.bls.gov/cew/datatoc.htm

Trade Exposure Measures. The number of workers employed in each of the four categories: high-wage tradable manufacturing, low-wage tradable manufacturing, high-wage tradable services, and low-wage tradable services. To categorize industries as tradable, we construct Gini coefficients of the geographic concentration of production for all U.S. industries in scope for the Economic Census for 1992. We classify industries as tradable if the Gini coefficient for the industry is above the threshold Gini coefficient that results in $90 \%$ of manufacturing sector employment being classified as tradable. We classify establishments as high-wage or low-wage using the median household income in the relevant year as the threshold for 'high wage.' Here, workers are classified as high-wage if the establishment in which they work has average wages above the median household income. We sum across establishments to construct the number of workers in each county that are in tradable industries with above-median income in the manufacturing sector, the number of workers in tradable industries with below-median income in the manufacturing sector, the number of workers in tradable industries with above-median income wages in the service sector, and the number of workers in tradable industries with below-median income wages in the service sector. The trade exposure measures are log (relevant employment measure + 1). Source: Census LBD. https://www.census.gov/ces/dataproducts/datasets/lbd.html

Demographic Data. The demographic data and other county-level controls are from the Decennial Census and American Community Survey. Election data are linked to the most proximate prior decennial census. Source: National Historical Geographic Information System (Minnesota Population Center at the University of Minnesota) https://www.nhgis.org/ 